\title{
How Effectively is the Cadet School Able to Develop Leaders of Character?
}

\section{Conor Gorey}

This article examines the ability of the Irish Defence Forces (DF) Cadet School to produce officers of character and competence. Character is central to the military leader; it is a requirement of mission command and it is a force multiplier in Peace Support Operations that the DF are engaged in. The article examines the literature surrounding character development and the structures in place in the Cadet School and the wider DF to support character development. This is compared to academic theories and international practices in other military academies. The article identifies the current processes, as they are understood by those who have instructed in the Cadet School and those who have recently passed through the training program. The article outlines how the processes in the Cadet School do develop character, primarily through the actions of the instructors but this is not supported by an explicit character development program. The article outlines a proposed framework for the development of a Character Education program encompassing existing structures, such as the Cadet School Ethos and the DF Values. This could be further used to operationalise the DF Values in action and enhance leader development across the DF.

The mission of the Irish Defence Forces Cadet School is to produce "officers with the essential values of character, leadership and competence" (Óglaigh Na hÉireann, 2016a). This is a lofty ambition to achieve with around 80 students, and constrained resources, in only 15-months. The mission statement, when critically examined, may in fact be unachievable; is it plausible that a person's character can be changed in such a short period of time? There are many factors that impact on the Cadet School mission and this paper will focus on the character aspect to assess if we are effectively developing character and if not, how best to develop this most potent component of leadership.

The idea of character and its components have been discussed since the times of Aristotle. A review of the literature indicates that there are diverse understandings of character, and how it can be developed. It is asserted that character can be imprinted, but how deeply it is imprinted and how this can be changed is the subject of much debate. At times it was suggested that character was no longer relevant, that it "is a Victorian idea, rightly abandoned along with the British Empire" (Goldie, 2004, p. 27). This thesis will argue that in an age of complexity, having leaders of character is essential because, as will be discussed, a leader of character is one who "in regard to others, always tries to do the right thing, for the right reason, on purpose" (Gini and Green, 2013, p. 35). 


\section{Research Aim}

The aim of this paper is to examine how effectively the Cadet School is able to develop leaders of character. It will examine the concept of character and its role in cadet education through a focus on the knowledge, understanding and structures in place dedicated to the development of character. The paper seeks to analyse how the Cadet School has integrated character education into its syllabus, across a whole-school approach and to reflect on the balance between character and competence development. In doing so, the paper will develop a thorough understanding of what character means, its relationship to the Defence Forces (DF) values and its importance to the leaders of the DF. It will apply international models for character development and assess if the Cadet School has adopted a systematic approach to ensure leaders of character and competence.

\section{Significance of the research}

Since 2016, the DF has noticeably increased recruitment in an attempt to address a retention crisis and decreasing numbers. A decision was also made to significantly increase the number of cadets inducted but there was no corresponding change in the systems or infrastructure used in their education. The systems in place in the Cadet School may not provide effective structures for personal growth and instead focus on evaluating and ranking performance, to the detriment of character development. There are academic and military perspectives which may provide some insight into how we can better produce leaders of character and competence.

The concept of leadership underpinned by character and competence is widely accepted in military academies as being essential to the development of all leaders, but particularly junior officers. Junior officers hold the rank of Captain and below and are key to the tactical leadership of the organisation. They are leaders who at the tactical level must "develop themselves and others, encourage others and train leaders to be the leaders they deserve to be" (Óglaigh Na hÉireann, 2016b, p. 6.6).

The military competence aspect of training is relatively straight forward, as all cadets must pass the specified exams, however efforts to ensure their character development may not be optimal. Character is deeply personal, influenced by life experiences, it can be shaped and moulded through appropriate education, training and aligned with the values of the organisation. Therefore, it can be developed in the Cadet School, if the right structures are in place.

The DF Values are Respect, Loyalty, Selflessness, Physical courage, Moral courage and, Integrity (Óglaigh Na hÉireann, 2016b). These have been championed by the Chief of Staff Vice Admiral Mellett and their importance was recognised by Uachtarán na hÉireann during his address to the DF Values Awards in September 2019:

Over a hundred years ago, Eoin MacNeill sought three qualities from those who had volunteered to serve in Óglaigh na hÉireann: courage, vigilance and discipline. These are the same attributes that are embodied in the oath taken by those who volunteer to serve in our modern defence forces. Members of the Army, Air Corps, and the Naval Service are expected, and 
indeed are proud to demonstrate these qualities in their daily duties.

Uachtarán na hÉireann, Michael D. Higgins cited in Molloy (2019).

These values are intricately linked to aspects of character and their importance is encapsulated in the President's address. Ensuring that we equip our future leaders with these values by means of character development is critical to the operational effectiveness of the organisation.

\section{PART ONE - Literature Review}

The development of character is fundamental to what the DF expects of its leaders and particularly in the Cadet School. Character development is a complex and intrapersonal issue that instructors and educators can only ever guide and facilitate, it is not a closed skill that can be instructed through traditional means. The literature concerning character development is multi-faceted and, as with any aspect of understanding human behaviour, there are multiple competing and conflicting theories.

\section{Character}

Peterson and Seligman outline the importance of character strengths which "are the bedrock of the human condition" (2004, p. 4). They ask many of the questions we must ask ourselves when it comes to the definition of character; is it passive or active? Is it intrinsic, does it exist in degrees or is it a condition "just something that someone happens, like pregnancy, to have or not" $(2004$, p. 5). The etymology of the word character comes from a Greek noun meaning

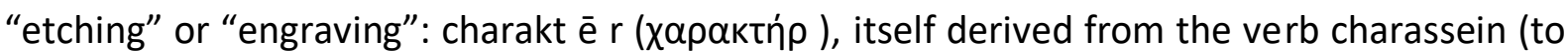
engrave) (Gini and Green, 2013, p. 10). This would imply that character is something that is imprinted upon us by our lived experiences leading to the question; is it possible to change the imprint once it has been made?

\section{Character or personality traits}

In much of the literature, the blurring of lines between character and character traits is evident. Character is generally considered a more enduring condition, reflecting lifelong practices and deep-set beliefs as described by Goldie (2004) and Banicki (2017). Character traits are often what we would describe as personality traits. The research on personality describes it as being shallow and more concerned with appearance (Danziger, 1997). Even the etymology of the term "personality" suggests superficiality by its relation to the Latin concept of persona: "a mask of the kind that used to be worn by actors" with character being deeper, what "emerges when the mask is removed" (Goldie, 2004, p. 13). Miller (2013) and Goldie (2004) both describe personality traits as being flexible and adaptable to the conditions prevalent at the time. Early writings on the dichotomy of personality traits and character focus on the distinction between fact and value, what is and what ought to be (Hume and Allport cited in Banicki, 2017, p. 59). The Big Five personality traits, also known as the five-factor model (FFM) and the OCEAN model (Ackerman, 2019), is a taxonomy for personality traits. The five factors are: Openness to experience; Conscientiousness; Extraversion; Agreeableness and; Neuroticism (OCEAN). Banicki (2017) argues that this strict dichotomy is not possible as personality and character are intertwined and that to understand character you must understand the prevalent conditions affecting personality traits as described in the OCEAN model. This sentiment is echoed by Gini and Green (2013) who believe that character must be 
understood in the context of culture, time, place and subjectivity. It is important to now identify the key components of character.

\section{Key components of character}

Across the literature there is a lot of commonality about the main aspects of character. RosMorente (2018) outlined character strength as being positive traits which are reflected at a cognitive, emotional and behavioural level. This bears close resemblance to the findings of Park, Peterson, and Seligman (2004) and Gini and Green (2013), who identify the presence of all three dimensions as being central to delineating character from personality. Carter (1996) suggests integrity is a kind of über-virtue or a type of "philosophical cement" that contains and coordinates all of one's other virtues and values. Devettere (2002) and Ros-Morente (2018) use the classical Greek readings to identify the six virtues and the key components of character (Table 1).

The "Classification of Virtues and Character Strength" provided in Table 1 is based on Niemiec (2013) and Peterson and Seligman (2004). The sub-definitions of these strengths are outside the scope of this paper, but a detailed analysis shows how each one can be broken down to provide evidence of actions that are conducted on the cognitive, emotional and behavioural levels, underpinned by integrity. Although there is agreement on the main aspects of character, it must be accepted that our understanding and therefore our character is influenced by our surroundings and must be understood in context.

\begin{tabular}{|l|l|}
\hline \multicolumn{2}{|l|}{ Table $\mathbf{1}$ Virtues and the key components of character. (Ros-Morente, 2018) } \\
\hline Wisdom & $\begin{array}{l}\text { Creativity, curiosity, open mindedness, love of learning and } \\
\text { perspective. }\end{array}$ \\
\hline Courage & Bravery, persistence, integrity and vitality. \\
\hline Humanity & Love, kindness and social intelligence. \\
\hline Justice & Citizenship, fairness and leadership. \\
\hline Temperance & Forgiveness, humility, prudence and self-regulation. \\
\hline Transcendence & $\begin{array}{l}\text { Appreciation of beauty, excellence, gratitude, hope, humour } \\
\text { and spirituality. }\end{array}$ \\
\hline
\end{tabular}

\section{Character is contextual.}

The nature of character can be described as very fluid and contextual. An individual's actions, although they may be classed as good, may not be reflective of good character if done for the wrong reasons. Goldie examined the relationship between action, motivation and consequences and also referred back to ancient Greece, identifying Aristotle's four conditions to measure if an action is indeed reflective of good character, "that he knew what he was doing; that his motive was characteristic of the virtue rather than self-regarding; that he acted out of a relatively enduring disposition; and that he had the right feelings" (2004, p. 37). This 
measurement of character is key to understanding the complexities of what it means to develop leaders of character.

Goldie also postulated that "character is much more fragile than we think" (2004, p. 35). It is this fragility that has traditionally been exploited in order to "break them down and build them back up again,' as the old military training adage puts it. This process is intended to strip away personality and demonstrate the underlying traits, that are more intricately linked with character. This fragility is reflected in Kegan's (1994) understanding of psychosocial development, explored in more detail later, which suggests that many undergoing military training will be particularly susceptible to change and development due to their age and stage of development. This literature is key to developing an understanding of character development training; that if we seek to influence an individual's character, the training institution has an obligation to put in place the morals, virtues and values that it espouses in order to ensure that the character forms in the desired mould.

\section{Character - a military perspective.}

\section{Irish Military Character}

The DF Leadership Doctrine (Óglaigh Na hÉireann, 2016b), is the capstone document for leadership training. It defines character as being "essentially who the leader is; the personal values and attributes of a leader that are inherent in the self" (Óglaigh Na hÉireann, 2016b, p. 5.1). This definition reflects many of the aspects of character examined earlier. The Cadet School learning environment seeks to ensure that the individual is orientated towards the values of the organisation and that the "personal and social values which are the bedrock of character and a leader's values must align with the organisational values" (Óglaigh $\mathrm{Na}$ hÉireann, 2016b, p. 2.4). This alignment is an essential point and is common across Western militaries.

Schein (1992) and Bardi and Schwartz (2003) outlined the importance of the environment in which character development takes place. This will be explored later, but the architecture of the DF Values is critical to this environment. These values which form the bedrock of the organisation are explained in Table 2.

\begin{tabular}{|l|l|}
\hline Table 2 DF Values (Óglaigh Na hÉireann, 2016b) \\
\hline Respect & $\begin{array}{l}\text { You must treat your comrades and those with whom you come } \\
\text { into contact, whether on operations or not, with dignity, } \\
\text { respect, tolerance and understanding. }\end{array}$ \\
\hline Loyalty & $\begin{array}{l}\text { You must be loyal to your commanders and your subordinates } \\
\text { and your team. }\end{array}$ \\
\hline Selflessness & $\begin{array}{l}\text { Your personal interests must come after the needs of the } \\
\text { mission and your team/unit. }\end{array}$ \\
\hline Physical courage & $\begin{array}{l}\text { You must have the physical courage to persevere with the } \\
\text { mission regardless of dangers and difficulties. Physical courage } \\
\text { comes with commitment and professionalism. }\end{array}$ \\
\hline
\end{tabular}




\begin{tabular}{|l|l|}
\hline Moral courage & $\begin{array}{l}\text { You must do what you know is right, not what is easier or } \\
\text { popular. }\end{array}$ \\
\hline Integrity & You must firmly adhere to a code of moral and ethical principles. \\
\hline
\end{tabular}

These values have been developed to be reflective of the unique character of the DF, our traditions and history and are also reflective of the values espoused by many other militaries. Crucially these values reflect the key components of character, Wisdom, Courage, Humanity, Justice, Temperance and Transcendence (Devettere, 2002, Ros-Morente, 2018). Numerous authors (Matthews et al, 2006, Boe and Bang, 2017) have drawn comparisons between these values and the mental and emotional strengths required of an army leader such as self-discipline, judgement, positive attitude and creative thinking (Table 3). It can therefore be asserted that the DF values are typical of character we should seek to develop in our leaders.

\begin{tabular}{|c|c|c|c|c|}
\hline $\begin{array}{l}\text { Character } \\
\text { Strengths } \\
\text { (Peterson \& } \\
\text { Seligman, 2004) }\end{array}$ & $\begin{array}{l}\text { DF Values } \\
\text { (Óglaigh Na } \\
\text { hÉireann, } \\
\text { 2016b) }\end{array}$ & $\begin{array}{l}\text { US Army } \\
\text { Values } \\
\text { (Headquarters } \\
\text { Department of } \\
\text { the Army, } \\
2015 \text { ) }\end{array}$ & $\begin{array}{l}\text { UK Army } \\
\text { Values } \\
\text { (UK Ministry of } \\
\text { Defence, 2014) }\end{array}$ & $\begin{array}{l}\text { New Zealand } \\
\text { DF } \\
\text { (New Zealand } \\
\text { Defence } \\
\text { Forces, 2017) }\end{array}$ \\
\hline $\begin{array}{l}\text { Justice } \\
\text { (Citizenship, } \\
\text { fairness) }\end{array}$ & Respect & Respect & $\begin{array}{l}\text { Respect for } \\
\text { others }\end{array}$ & Comradeship \\
\hline $\begin{array}{l}\text { Humanity } \\
\text { (kindness and } \\
\text { social } \\
\text { intelligence) }\end{array}$ & Loyalty & Loyalty & Loyalty & \\
\hline \multirow{2}{*}{$\begin{array}{l}\text { Temperance } \\
\text { (humility, self- } \\
\text { regulation) }\end{array}$} & Selflessness & Selfless service & $\begin{array}{l}\text { Selfless } \\
\text { commitment }\end{array}$ & Commitment \\
\hline & Integrity & Integrity & Integrity & Integrity \\
\hline $\begin{array}{l}\text { Courage } \\
\text { (Bravery, } \\
\text { integrity) }\end{array}$ & $\begin{array}{l}\text { Physical } \\
\text { courage }\end{array}$ & $\begin{array}{l}\text { Personal } \\
\text { courage }\end{array}$ & Courage & Courage \\
\hline Wisdom & $\begin{array}{l}\text { Moral } \\
\text { courage }\end{array}$ & Honor & Discipline & \\
\hline Transcendence & & Duty & & \\
\hline
\end{tabular}

The importance of character to the military goes beyond just ethical matters and it calls on leaders of character for its operational philosophy. The Mission Command philosophy is 
favoured by many Western forces, including the DF (Óglaigh Na hÉireann, 2015, p. 8-5) and is crucially linked to character. It is critically important in modern operations "as the uncertainty of operating environments dictate, junior leaders need to be capable of independent decisions using sound discretionary judgments founded in moral character" (Headquarters Department of the Army, 2015, p. 5-1). This can only be achieved where the character of our leaders is trained and developed to be in line with our organisational values.

\section{Military Character internationally}

The West Point Military Academy (WPMA) has developed the West Point Leader Development System (WPLDS) and Character Development Program, Gold Book (United States Military Academy, 2018). The WPLDS defines a leader of character as one who "lives honorably, leads honorably, and demonstrates excellence" (West Point Military Academy, 2018). The WPLDS breaks character further down into five facets (Table 4).

\begin{tabular}{|l|l|}
\hline Table 4 WPLDS (West Point Military Academy, 2018) \\
\hline Moral & Display integrity and honor \\
\hline Civic & Have empathy and do more than your share; \\
\hline Performance & Accomplish goals and be resilient; \\
\hline Social & Live honourably in both public and private life; \\
\hline Leadership & Positively influence others. \\
\hline
\end{tabular}

They reflect a blend of structural and content-based learning that promotes the four factors of moral, virtuous, consistent, and intentional actions that underpin our understanding of character. The US Army Leadership Development manual reflects these beliefs and insists that character can be developed over time, with practice and in an iterative process (Headquarters Department of the Army, 2015, p. 5-1). The UK's Developing Leaders - A British Army Guide (UK Ministry of Defence, 2014) also outlines the role of leaders of character and how they can be developed within a leadership framework.

\section{A definition of character}

Character is the internal thought processes, motivations and actions carried out by a person. There are six key components of character: Wisdom, Courage, Humanity, Justice, Temperance, and Transcendence (Ros-Morente, 2018). These are reflective of the virtues espoused in that person's cultural upbringing and underpinned by their integrity. The DF Values are an accurate reflection of the type of character we should seek to develop. Character is a learned behaviour as well as a skill that must be practiced in order to become reflexive and consistent. Character can be developed using the right tools, assuming those tools are in place. 


\section{Understanding Character Development}

To better understand character development, it is essential to understand the theories behind psychosocial development. These theories will be examined in three main groups, Depth Psychology, Behaviourism and Stage Development Theories.

Depth Psychology is the body of work that refers to the psychoanalytic approach to understanding the links between the conscious and the unconscious. The phrase was coined by Eugen Bleuler in 1914 and was a development on the theories of Sigmund Freud, looking at how the id, ego and superego affect psychological development, human behaviour and relationships (Ellenberger, 1970). This term was accepted by Freud and was built on by Carl Jung and others to explore the relationships between the different psychic systems (Jung, Read, Fordham, and Adler, 1983).

Behaviourism is primarily concerned with observable, classifiable behaviours. It emerged from the works of John B. Watson in reaction to Depth Psychology, choosing to focus on behaviour rather than internal mental and emotional factors. This work was developed further by B. F. Skinner and others asserting that "human and animal behaviour can be explained in terms of conditioning, without appeal to thoughts or feelings, and that psychological disorders are best treated by altering behaviour patterns" (McLeoud, 2017, p. 56). This field assumes that humans are basically passive learners who respond to stimuli, developing over time through experiential learning (Skinner, 1971).

The cognitive or stage development theories of Piaget, Erikson and Kohlberg outline how people develop at different stages of their life and how these affect our behaviours and moral reasoning. Piaget (1972) was the pioneer of this theory and considered intelligence, thought organisation and adaptation to the environment in terms of progressive steps from birth through adolescence and adulthood. Although his theory has been challenged, it has also been elaborated and expanded upon and went on to provide the foundations for many others (Fisher and Lerner, 2005). Erikson's theory of eight stages of psychosocial development (1959) built on the work of Piaget, examining how the ego and cultural and social influence cut across one's lifespan. Kohlberg also expanded upon Piaget's theory, bringing in the moral reasoning behind cognitive development, which is essential to the understanding of character. Kohlberg (1971) outlined three stages (Table 5).

Table 5 Kohlberg's Theory of Moral Development

\begin{tabular}{|l|l|}
\hline Pre-conventional & $\begin{array}{l}\text { Morality is judged by its consequences of the } \\
\text { action 'will I get in trouble' (common in children). }\end{array}$ \\
\hline Conventional & $\begin{array}{l}\text { Morality is judged in comparison to social norms } \\
\text { and expectations 'what will people think of me' } \\
\text { (seen in adolescents and adults). }\end{array}$ \\
\hline Post-conventional or principled & $\begin{array}{l}\text { The individual sees themselves as an independent } \\
\text { moral agent, acting in accordance with their own } \\
\text { ethical principles. }\end{array}$ \\
\hline
\end{tabular}


Gilligan (1982) challenged Kohlberg's model, arguing that the moral orientation of individuals is also important to understanding development. Gilligan suggests that the moral orientation is a typological construct and that early gender socialisation means that men are more likely to use a justice orientation, focusing on adjudicating competing claims and rights and women a care orientation, focusing on preserving and enhancing relationships. This contrasts with Kohlberg's hierarchically ordered stages. One effort to synthesise these theories is Kegan's stages of psychosocial development.

Kegan's (1994) work focuses on the individual's ability for self-development. His theories are based around 'meaning making' and are closely related to Kohlberg's stages of moral reasoning. Kegan's stages (Figure 1) also show a cyclical or helical sequence of alternating focus on issues of autonomy/separation, versus issues of inclusion/connectedness, paralleling the orientation concepts suggested by Gilligan but without the idea of gender socialisation Gilligan favoured (Pratt and Diessner, 1991).

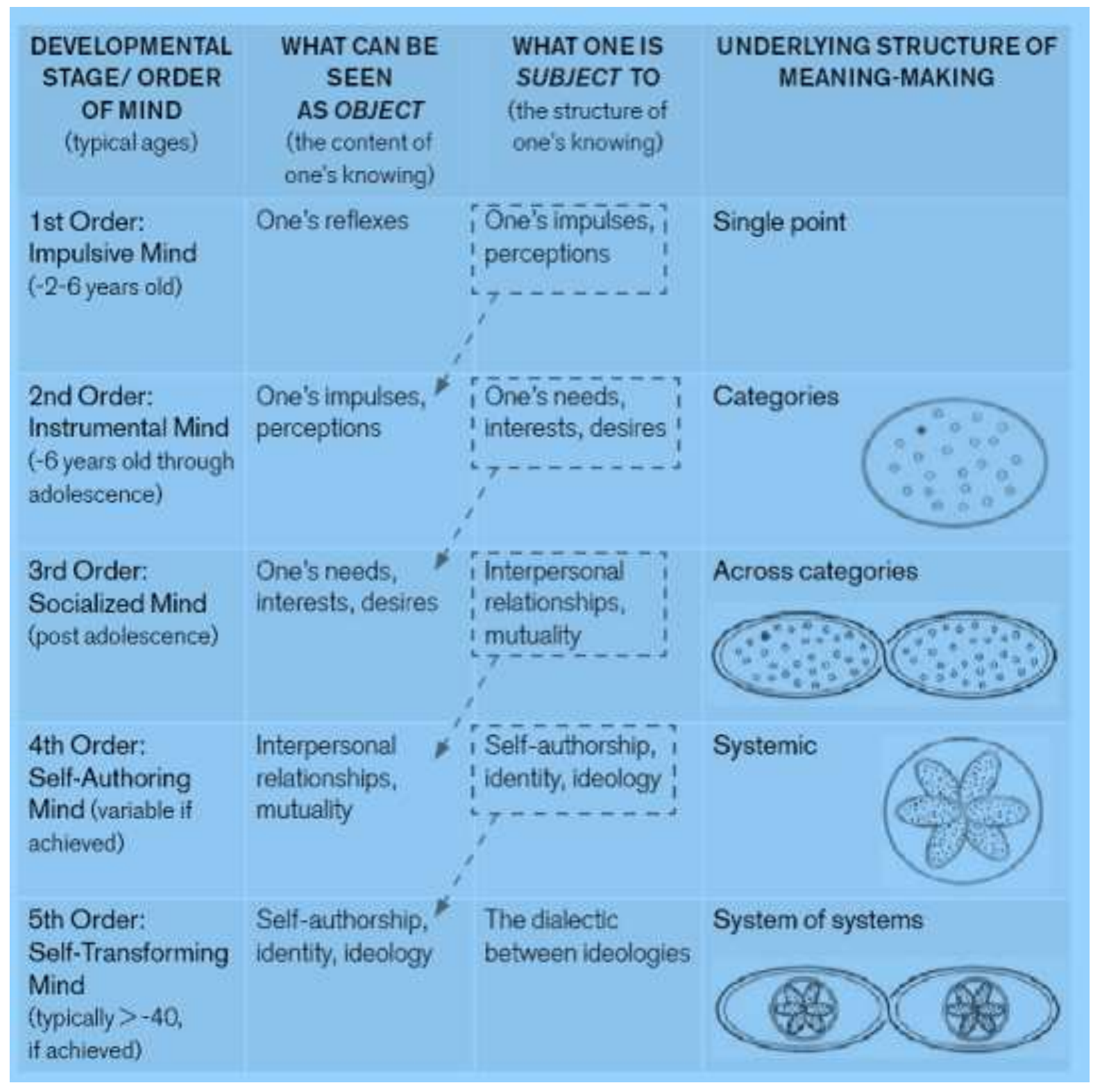

Figure 1. Kegan's Stages of psychosocial development

(Figure taken from Kegan 1994) 
These three theories frame our understanding of psychosocial development, the moral component of which is intricately linked to character development. Kegan's model is most developed in terms of applicability to character and how it can be developed in a military context as will be discussed later in this paper.

\section{Character development}

Character is more to be praised than outstanding talent. Most talents are to some extent a gift. Character, by contrast, is not given to us. We have to build it piece by piece - by thought, choice, courage, and determination. John Luther (2009)

Character development is "continuous, lifelong, and achieved within the programmes that develop competence and commitment - through education, training, and experience" (Center for the Army Profession and Ethics, 2016). The 1992 Aspen Declaration on Character Development outlined that "people do not automatically develop good moral character; therefore, conscientious efforts must be made to help young people develop the values and abilities necessary for moral decision making and conduct" (Josephson, 1992). It is therefore essential to examine what tools are available to develop character.

\section{Character is a learned behaviour.}

Solomon (1996) describes character using the metaphor of a vessel that needs to be filled up, and that which fills it is our experiences in life and how we interpret them. This theme is common across much of the literature but there is little consensus that character can be truly changed through education alone (McGrath, 2018), without considering the environmental conditions and experiential learning required. Some argue that character is innate and others that it is "like a skill, athletic ability, or musical talent, must be practiced in order to be perfected and maintained." (Gini and Green, 2013, p. 37). Factors as outlined by Gini and Green (2013) such as custom, personal interpretations, cultural identity and the time and place in one's life where the experiences occur have a major impact on our character development. This correlates with Kegan's (1994) theories as discussed and it can therefore be argued that our character is shaped by our experiences and that through education, the correct environment and reflective practice we can indeed develop character.

\section{The development of character}

Over the past 50 years there has been a move to a more research-based approach to character development from the anecdotal evidence that had been popular. As discussed, there is no consensus on the definition of character and there remains ambiguity surrounding the optimal method to develop character (Center for the Army Profession and Ethics, 2016). Therefore, the factors that impact character development must be examined.

As previously discussed, there are many developmental theories that outline psychosocial development such as Erikson $(1968 ; 1982)$ and Kegan (1994). Kegan's theory describes how individuals in the age range of the average cadet (22 years old for Cadets trained 2016-19) will be undergoing "major qualitative shifts in how people construct their understandings of the world around them and their own place in it" (1994, p. 38). Kegan describes six stages of development and emphasises both psychological and social factors in 
development. How these are influenced through the feedback and appraisal systems of the Cadet School will play a significant role in this development.

No man is an island and Schein (1992) provides critical insight into the effects of culture and climate of the environment on character development, and this must be borne in mind by the Cadet School and the wider DF. The DF Leadership Doctrine (Óglaigh Na hÉireann, 2016b) defines the DF Values and provides criteria for the cultural environment of the organisation and for character development. What happens in the environment, what is expected and valued by the group are critical development factors (Schein, 1992). Bardi and Schwartz (2003) use the analogy of "bad apples versus bad barrels" to outline the symbiotic relationship between individuals (apples) and culture/environment (barrels). It is crucial to provide the right learning environment for the development of character.

The type of environment provided must be conducive to character development. Damon (2002; 2008) notes that we cannot separate the moral from the intellectual components of character development. In his later work, Damon (2011) explores how the environment can lead to a decline in concern for character and moral values where the importance of these values is not made relevant or central to education. Damon also examines how people can exert control over their everyday choices through the practice of honesty, humility and faith (Damon and Colby, 2015). The importance to character development of giving people these choices should not be underestimated.

The complexity of the interplay between multiple dimensions has been outlined by Berkowitz (2012) who outlined the risk of applying a taxonomic approach. He further criticised the works of Peterson and SiegIman (2004) for describing character without examining how it can be developed. The influence of societal institutions and culture on the cognitive, affective and behavioural domains impacts on how character has been explored through the works of Narvaez (2008) and Berkowitz (2012). This interplay is also recognised as non-linear and uniqe to the individual (Overton, 2015).

The theories outlined above highlight that character development is a complex interaction between psychosocial development, the environment the development takes place in and the influence exerted to direct the manner of development. These factors need to be understood and considered in mapping the course for character development and how we approch this learning.

\section{An approach to learning}

Tell me and I forget, show me and I remember, involve me and I understand. Chinese Proverb

Adult education is an ancient concept with "the great teachers of ancient times, Confucius, Moses, Jesus, Aristotle, Socrates, Plato and Cicero, all being teachers of adults" (Knowles, 1998, p. 6). The Government's White Paper on Adult Education (Department of Education and Science, 2000) recognises that adult learning is "primarily undertaken on a voluntary, selfmotivated basis and in a context where the learner, rather than the provider, is the centre of the process" (Department of Education and Science, 2000, p. 32). This adult learner paradigm is linked to Kegan's stages of psychosocial development and both should be applied in developing an appropriate adult learning model. 
Weimer (2002) outlines what it means to provide a student-centred learning experience which is what the Cadet School aspires to provide. She outlines five areas which can be used to measure whether a system is in fact student centred;

- The balance of power;

- The function of content;

- The role of the teacher;

- The responsibility of learning;

- The purpose and processes of evaluation.

Brown Wright (2011) expands this into higher education and these findings should be a key driver for the development of character in an adult learning structure. These factors point to the need for a model of learning that uses a reflective approach in order to ensure that students are challenged, encouraged to reflect and to develop the ability to guide their own development as part of a life-long learning process. There are various educational models that outline how this can be achieved.

Bloom's taxonomy remains a valid method of assessing a student's level of understanding in a subject or in a cognitive domain. This model outlines six stages from knowledge to evaluation and can be applied to character development but is more relevant to competence (Krathwohl, 2010). Felder's Learning model incorporates four dimensions: active, sensing, visual and sequential. It is focused on assessing the learners' style, outlining a sliding scale on four dimensions (Nafea, Siewe, \& He, 2019). This allows the educator to assess their own preferences and the likelihood of a student engaging in a practice of reflective learning but does not necessarily provide a model for character development learning. Kolb's experiential learning cycle (Figure 2) proposes a model where a learner can move through four stages: concrete learning, reflective observation, abstract conceptualisation, and active experimentation. This model fits the requirements for character development and is a lifelong learning tool (Manolis, 2013). While elements of Bloom's and Felder's works are important to understanding, Kolb's model is potentially a much more relevant tool for character development in the military. It is linked to the US Military fundamentals of Developing Leaders Model and is considered a valid model for experiential learning in the military (Headquarters Department of the Army, 2015, p. 3-2). 


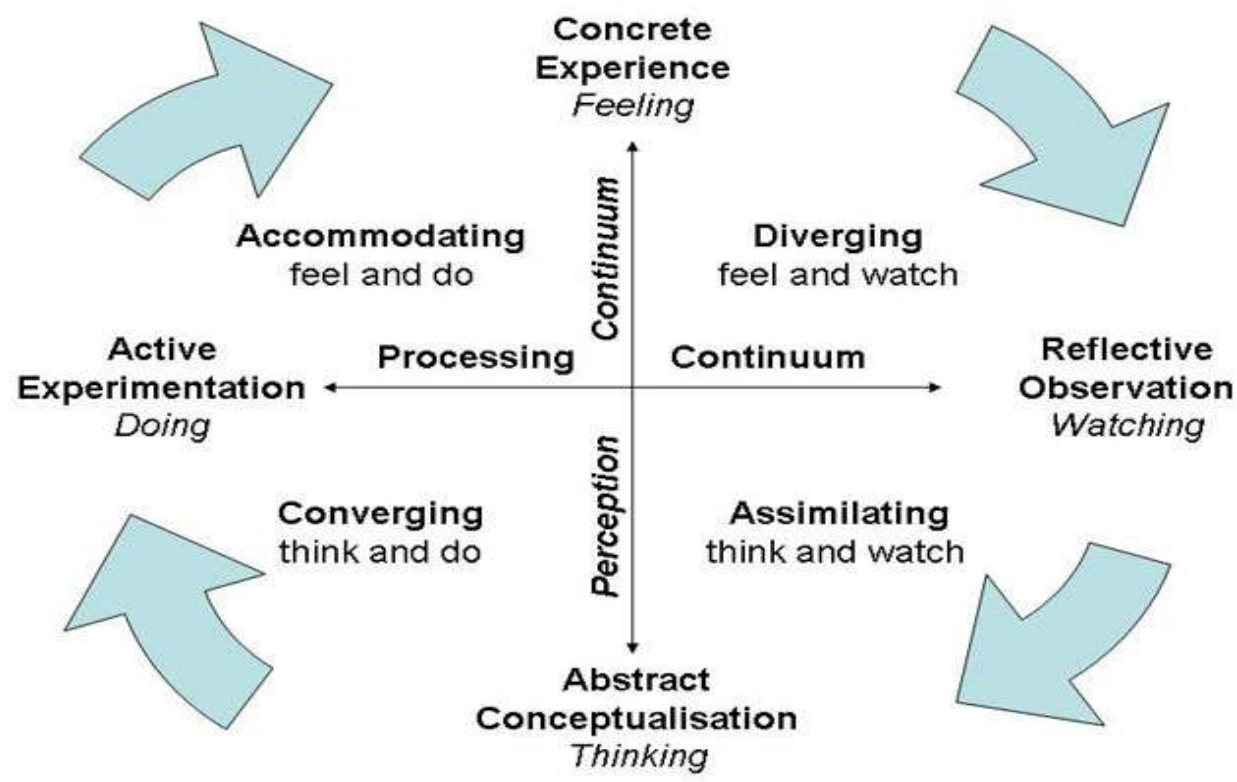

Figure 2. Kolb's Experiential Learning Cycle (Figure taken from McLeoud, 2017)

\section{A tool for character development}

McGrath (2018) surmises that the root problem with understanding character development is that across all the literature there are a substantial number of variables in the definitions. Berkowitz (2012) focused on the ethical and socially beneficial behaviours, where as Tough (2011) focused on seven characteristics which essentially have no aspect of social or moral actions. Each study has revised, minimized, expanded or rejected aspects of the other studies, making an all-encompassing definition difficult. McGrath (2018) proposes a model for character education encompassing the following:

- School based;

- Structured;

- Positive psychological attributes;

- Identity;

- Moral growth;

- Holistic growth;

- Develops practical wisdom.

Berkowitz, Bier and McCauley (2017, p. 38) conducted an extensive review of the major character development paradigms and proposed the PRIMED model (see Table 6). 


\begin{tabular}{|c|c|}
\hline Prioritization & $\begin{array}{l}\text { Of character and social emotional development in } \\
\text { school }\end{array}$ \\
\hline Relationships & $\begin{array}{l}\text { Strategic and intentional promotion of healthy } \\
\text { relationships among all school stakeholders }\end{array}$ \\
\hline Intrinsic Motivation & $\begin{array}{l}\text { Promotion of the internalization of core values/virtues } \\
\text { through intrinsic motivational strategies }\end{array}$ \\
\hline Modelling & $\begin{array}{l}\text { All adults and older students model core values/virtues } \\
\text { and socioemotional competencies }\end{array}$ \\
\hline Empowerment & $\begin{array}{l}\text { Schools empower all stakeholders as co-owners and co- } \\
\text { authors of the character education initiative and the } \\
\text { school in general }\end{array}$ \\
\hline Developmental Pedagogy & $\begin{array}{l}\text { Schools intentionally foster the development of student } \\
\text { character and socioemotional competence and utilize } \\
\text { methods that are developmental in purpose. }\end{array}$ \\
\hline
\end{tabular}

This model has synthesised many of the theories and provides a useful lens to view character development structures and sits between a pedagogical and andragogical approach. Bleich (2015) uses the term "crucible moments" for critical moments that lead to the development of character. Crucible moments are particularly common in front-line services and these must be capitalised upon in order to maximise and guide character development. Bleich also posits that periods of education are a crucible in themselves and this is certainly true of the Cadetship. Crucible moments occur throughout the training and structures must be in place to ensure that cadets are given the tools to maximise these moments.

The US Army Leader Development Plan (Headquarters Department of the Army, 2015, p. 7-2) proposes a more reflective style for feedback that adopts a structured, coaching and mentoring style identifying the strengths, needs and underlying causes. This is comparable to Kolb's system, offering a feedback, study, practice loop which ensure that an individual's character is developed in line with the values of the organisation. This is in addition to experiential learning and coaching techniques such as open-ended questions, promoted in McGrath's (2018) model for character education. The focus is on how to think, not what to think and allowing an individual to demonstrate character through their decisions.

While the language used is different, there are many common themes across these theories. There is a requirement for whole school effort, a conscious focus on moral character development, the importance of role modelling and the central role the student plays in directing their own learning. These definitions outline the fundamentals for the development of a model for character education and inform the understanding of the elements at play in the Cadet School. 


\section{Character development in the Cadet School}

The Standard Cadet Syllabus states it provides "a learning environment with a student-centred approach which encourages the realisation of full potential" (Óglaigh Na hÉireann, 2016a). Commandant Cathal Keohane, speaking as Chief Instructor of the Cadet School outlines how the Cadet School attempts to formally assess "the intangible aspects of their character" (Keohane, 2019, p. 23) through various arduous training scenarios, crucible moments which "provide windows into the students character" $(2019$, p. 23). He further goes on to suggest that it is during these trying times that we can truly assess character. This is at the heart of most military training, that through hardship we can see true character and "sufficient grit." This approach must be examined in context of the formal tools used in the Cadet School to develop character. The ethos of character and character development is laid out in the Cadet Schools Standing Orders (Óglaigh Na hÉireann, 2017), where Sections 19 and 20 outline the code of behaviour for cadets and staff respectively. The Code of Conduct for cadets refers to the words of the commission for which they are being prepared for "the special trust and confidence placed in the military officer demands the embracing of a rigorous ethical code" (Óglaigh Na hÉireann, 2017, p. 44). These two documents are key to understanding the structures in place to ensure the development of the cadets' character.

Scott-Lennon and Barry (2008, p. 31) state "not all goals can be expressed in measurable terms" citing leadership and motivation as typical examples; qualities, which are essential to the development of military officers of character. The focus of the Cadet School's syllabus is on measurable assessments as a means of grading and ranking cadets (Óglaigh Na hÉireann, 2016a). The Cadet School's tool for tracking or shaping character development is the LA 150A 'Character and Leadership Assessment' table (Óglaigh Na hÉireann, 2012b) outlines 21 areas that can be measured, including areas such as Motivation/Enthusiasm, Self-Confidence, Integrity and Resilience (Table 7). This table reads more like a performance appraisal (Table 8) than a tool to develop character, although it does include aspects of character, such as integrity, respect, and moral courage. 
Table 7 LA 150A Character and Leadership Assessment

\section{CHARACTER \& LEADERSHIP ASSESSMENT}

\begin{tabular}{|c|c|}
\hline Self-Discipline/Conduct & $\begin{array}{l}\text { The ability to display self-discipline and the highest standard } \\
\text { of conduct on all occasions. }\end{array}$ \\
\hline Motivation/Enthusiasm & $\begin{array}{l}\text { Possessing keenness, drive, commitment and zeal in the } \\
\text { execution of duty. }\end{array}$ \\
\hline Self-Confidence & $\begin{array}{l}\text { The ability not just to act within his/her own limitations, but } \\
\text { also to operate outside his/her comfort zone. }\end{array}$ \\
\hline Integrity & $\begin{array}{l}\text { The capacity to regulate his/her life according to a proper } \\
\text { sense of right and wrong. }\end{array}$ \\
\hline Resilience & $\begin{array}{l}\text { Mental strength, ability to deal with pressure, criticism and } \\
\text { the restrictions inherent in cadet training. }\end{array}$ \\
\hline Military Bearing & $\begin{array}{l}\text { High standards of dress, bearing and deportment both on and } \\
\text { off duty. }\end{array}$ \\
\hline Selflessness & $\begin{array}{l}\text { Placing the needs of the Defence Forces and his/her fellow } \\
\text { cadets before personal interest. }\end{array}$ \\
\hline Respect & $\begin{array}{l}\text { The cadet must have respect not only for himself/herself, but } \\
\text { also for those with whom he/she comes into contact with. A } \\
\text { cadet must demonstrate respect, dignity, tolerance and } \\
\text { understanding. }\end{array}$ \\
\hline Reliability & $\begin{array}{l}\text { General reliability on and off duty - trustworthiness, } \\
\text { dependability, conscientiousness and thoroughness } \\
\text { necessary to see a task through to its conclusion. }\end{array}$ \\
\hline Teamwork & Ability to work with and gain the support of others. \\
\hline Social Conduct & $\begin{array}{l}\text { Ability to socialise with fellow cadets, staff and others with } \\
\text { whom they come in contact with as part of their training. }\end{array}$ \\
\hline Authority in Command & $\begin{array}{l}\text { Firmness and strength of purpose; projection of a course of } \\
\text { action. }\end{array}$ \\
\hline Initiative & $\begin{array}{l}\text { Quickness of mind and immediate grasp of essentials that } \\
\text { enable the cadet to sum up a situation and take the initiative. }\end{array}$ \\
\hline Judgement & $\begin{array}{l}\text { Sense of proportion. The possession of sound and balanced } \\
\text { judgement. }\end{array}$ \\
\hline Decisiveness & Ability to make decisions and take action. \\
\hline Moral Courage & $\begin{array}{l}\text { The courage to follow what is honest and within the Code of } \\
\text { Behaviour, without fear of the consequences. }\end{array}$ \\
\hline Organisational Skills & $\begin{array}{l}\text { The capacity and foresight to plan so as to meet successfully } \\
\text { the needs of any situation. The recognition of priorities, } \\
\text { controlling, evaluating and supervisory abilities. }\end{array}$ \\
\hline Communication Skills - Written & The ability to use language clearly and effectively in writing. \\
\hline Communication Skills - Oral & The ability to use language clearly and effectively in speech. \\
\hline Professional Competence & $\begin{array}{l}\text { The knowledge and skills required for the job of a Light } \\
\text { Infantry Platoon Commander. }\end{array}$ \\
\hline Physical Robustness & $\begin{array}{l}\text { Ability to perform under pressure in conditions of stress, } \\
\text { demonstrating firmness of purpose, agility and co- } \\
\text { ordination. }\end{array}$ \\
\hline
\end{tabular}


Table 8 AF667 Part 3, Other Ranks Detailed Assessment

\section{PART 3: DETAILED ASSESSMENT}

\section{COMPLETED BY REPORTING OFFICER (COMPLETE WITH [X])}

+

\begin{tabular}{|c|c|c|c|c|c|c|}
\hline & $\begin{array}{l}\text { QUALITIES } \\
\text { /ATTRIBUTES }\end{array}$ & $\begin{array}{l}\text { OUT- } \\
\text { STANDING }\end{array}$ & $\begin{array}{l}\text { ABOVE } \\
\text { AVERAGE: }\end{array}$ & AVERAGE & $\begin{array}{l}\text { BELOW } \\
\text { AVERAGE }\end{array}$ & INADEQUATE \\
\hline a. & Ability & & $\mathbf{x}$ & & & \\
\hline b. & $\begin{array}{l}\text { Cooperation/Team } \\
\text { Spinit }\end{array}$ & $\mathrm{x}$ & & & & \\
\hline c. & Industry/Zeal & & $\mathrm{X}$ & & & \\
\hline d. & Initiative & $\mathbf{x}$ & & & & \\
\hline e. & Firmness in Control & & $\mathrm{X}$ & & & \\
\hline f. & $\begin{array}{l}\text { Attitude to } \\
\text { Superiors }\end{array}$ & $\mathrm{x}$ & & & & \\
\hline g. & Tact & $\mathrm{x}$ & & & & \\
\hline h. & Quality of Work & & $\mathrm{x}$ & & & \\
\hline i. & Devotion to Duty & $\mathrm{X}$ & & & & \\
\hline 1 & Dress/Appearance & $\mathrm{X}$ & & & & \\
\hline k. & $\begin{array}{l}\text { Intelligence, Powers } \\
\text { Of Comprehension }\end{array}$ & & $\mathrm{x}$ & & & \\
\hline 1. & $\begin{array}{l}\text { Judgement and } \\
\text { Commonsense }\end{array}$ & & $\mathrm{x}$ & & & \\
\hline $\mathbf{m}$. & Leadership & & $\mathrm{X}$ & & & \\
\hline n. & Loyalty & $\mathrm{x}$ & & & & \\
\hline a. & Physical Fitness & $\mathrm{x}$ & & & & \\
\hline p. & Reliability & $\mathrm{X}$ & & & & \\
\hline q. & $\begin{array}{l}\text { Willingness to accept } \\
\text { Responsibility }\end{array}$ & $\mathrm{x}$ & & & & \\
\hline & TOTALS & 10 & 7 & & & \\
\hline
\end{tabular}

relevant heading thus "N/A".

As the LA150 Character and Leadership Assessment acts as both an assessment and appraisal tool, it should be examined to see if it is appropriate for either role. Armstrong (2009) outlines the performance appraisal process as being based on two-way communication, review and feedback. According to Armstrong (2009) it is in the performance planning phase that expectations, goals, performance indicators and measurements should be agreed and laid out. Both sides should have an input at this stage and that the criteria for the selection of objectives should be specific, measurable, achievable, relevant, and time-framed (SMART). As there is no two-way process involved, it is difficult to describe the LA150 as an appraisal tool or as an effective means of developing character.

Bartone et al (2007) conducted a longitudinal study on the developmental processes and factors that may be associated with positive leader outcomes and performance in the WPMA using Kegan's theoretical framework. The findings of this paper depicted clear forward progression throughout the four years, but significantly showed that the increase occurred in the critical areas only after year three of the programme. This has implications for the Cadet School as with only 15 months in which to achieve character development, its methods must focus on training and education most likely to promote psychosocial growth, i.e. to develop character.

Using the PRIMED model as a lens, a review of the character development tools and processes in the Cadet School highlight the lack of a clear and specific character development programme. The merger between assessment, appraisal and development creates challenges for effective character development and are not consistent with McGrath's (2018) model described earlier. The current system can be described as using the Cadet School ethos to 
support three pillars; structures, knowledge, and development, to train cadets so that they understand the DF Values and are competent to be commissioned (Figure 3).

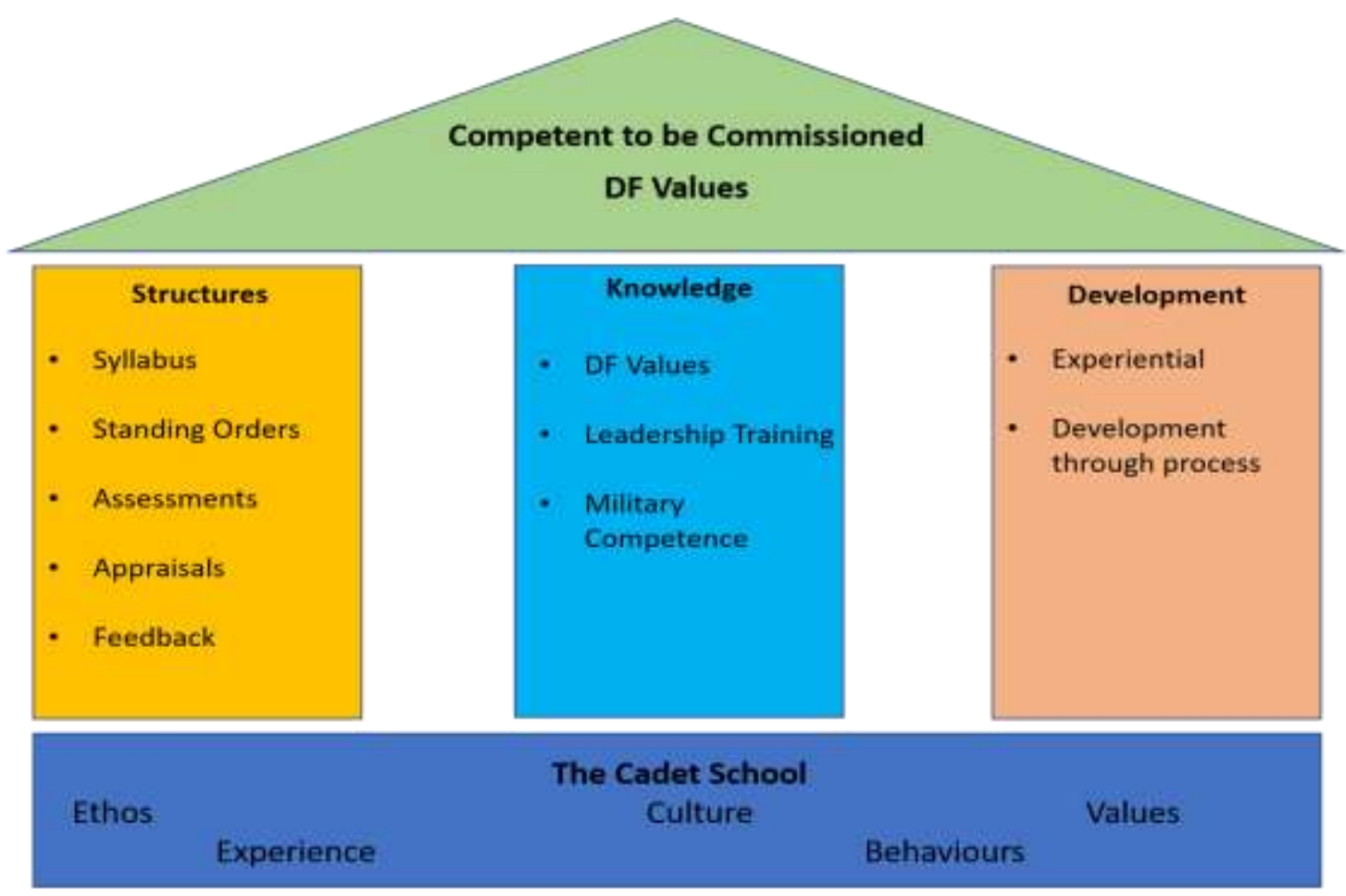

Figure 3. Conceptual Framework for competence-based program (by author)

With only 15 months to provide this development, the degree to which this can be achieved should be considered. The existing system has been strained by the significant increase in numbers of cadets, without a proportional increase in permanent instructor and counsellor staff. This increase has also impacted on the environmental conditions which play a significant role in learning and development, as discussed earlier in the works of Bardi and Schwartz (2003). As a result, the education model and environment in the Cadet School may not support character development.

\section{Conclusion}

Many people, consciously or not, associate character with the classical Aristotelian model of character: a person who is a paragon of virtue, a person who is completea model of excellence and a bedrock of integrity. (Gini and Green, 2013)

The review of the literature has examined the understanding of character and its relevance to the modern military leader and has shaped an understanding of how character is developed in the Cadet School. Character is a deeply personal thing, imparted by our life experiences; it can be shaped and moulded through proper education, environment and training which are aligned with the values of the organisation. Therefore, we can develop leaders of character in the Cadet School. However as outlined, the systems in place in the Cadet School may be lacking by not providing a student-centric learning environment or promoting personal growth, instead focusing on evaluating and ranking performance, to the detriment of character development. The works of Kegan and Kolb provide a theoretical framework that can be applied to character development. In addition the PRIMED Model of Berkowitz, Bier and McCauley (2017) provide a guide as to how this can be applied to the learning structures 
in the Cadet School. The idea of crucible moments providing opportunities for character development and the practices used in other militaries may provide some insight into how we can develop a more balanced approach to developing leaders of character and competence.

Part Two will outline the methods employed to gather the information and opinions of the people about current character development in the Cadet School from people who are involved in the process at various levels.

\section{PART TWO - Methodology}

Two methods were used for gathering qualitative data; focus groups and a series of semistructured interviews. The focus group was designed to provide rich qualitative data, developed through discussion within the group. The focus groups and interviews are sequenced to move through the Cadet School hierarchy, allowing an active reflexivity to the research. This gave a multi-point reference to gain an understanding of character and its development in the Cadet School from various aspects.

The initial step was a focus group, as it supports the post-positivist, qualitative mode of inquiry. The value of the focus group espoused by Bryman "allows the researcher to develop an understanding about why people feel the way they do" (2008, p. 475). This method allows the group to create new knowledge through shared experiences. The questions were designed using Krueger and Casey's guide for focus groups, with an emphasis on one-dimensional, open-ended questions to generate discussions (2000, pp. 40-43). The focus group consisted of 12 officers commissioned in the previous three years. The size of the focus group was larger than that recommended by Krueger and Casey, but this was to construct an accurate representative body and give greater depth to the information gained. This risk was offset by using four groups of three to discuss each question before a group discussion. In addition, the relative familiarity and homogenous nature of the group meant that the discussions were focused and provided relevant information. The focus group was structured to attempt to generate discussion amongst students around their experiences of character development and their information was used to create a thematic approach for the data analysis and the subsequent interviews.

The focus group was followed by a sequential set of interviews moving through the Cadet School hierarchy to establish a common understanding of character and its development. Semi-structured interviews were used as they provide a "rich, nuanced, descriptive data that reflect[ed] the interviewee's understanding of her/his life-world" (Antonesa, et al., 2006, p. 77). The questions for the interviews were derived from the information gained through the focus groups to allow for thematic data analysis. The questions evolved as the series of interviews progressed. The interviews were conducted sequentially with officer instructors, the School Commandant of the Cadet School, Professor Kilner from WPMA and the Assistant Chief of Staff (ACOS).

The interviews were structured to address the gaps identified in the literature and were done sequentially, with each level being used to further develop or refine the questions being asked while addressing the core concepts. Having confirmed a baseline level of understanding with the focus group and instructors, the questions for the School Commandant became more about education structures, while the questions with the ACOS focused more on the intellectual component and relevance to the wider DF. The nature of the semi-structured 
interviews meant that the interviewees were given latitude to give a broader perspective on the subject, relative to their position.

\section{Sampling}

The sample selection method used in the focus group design was that of representative sampling as "having a representative sample rather than a random sample would be the better option" (Fielding and Gilbert, 2012, p. 227). This sample method is, according to Fielding and Gilbert almost impossible to obtain as "the sample needs to be representative not just on one, but on every characteristic that could be relevant" (2012, p. 227). In order to try to achieve a representative sample I selected a group based on what I saw as the key variables in character development, age, gender, academic qualification (school leaver, some $3^{\text {rd }}$ level education and graduate) and those with previous military service. While there are many other variables, this provided greater confidence in the results than would be achieved using a truly random sample.

For the interviews I selected the interviewees using an elite sampling method. Such a sampling method was necessary to obtain "information rich and illuminative" (Patton, 2014, p. 40) sources, thereby allowing for a greater depth of understanding of the phenomenon of character development in the Cadet School. This elite sampling was done at the level of officer instructor and above with each having a unique and diverse perspective. As with the authors bias, the unconscious bias of the instructor staff had to be borne in mind, as they would be discussing a matter with which they had been intimately involved.

Lieutenant Colonel (Lt Col) Gavin Young was the School Commandant of the Cadet School at the time of interview. He served as the School Commandant for a period of two years and oversaw three cadet classes and a Potential Officers Course. The next interview was with Prof. Peter Kilner, the John Hottell Chair for Character Development, WPMA, United States. Prof. Kilner is the author of more than 80 books and articles on ethics, leadership, and organizational learning. His work on military ethics has been featured in the Washington Post, the Wall Street Journal, New Yorker, Military Review, Army magazine, NBC Dateline, PBS, BBC, NPR, and the film Soldiers of Conscience. He writes and speaks extensively on the morality of killing and war-related moral injury.

The final interview was with Brigadier General (Brig Gen) Adrian Ó Murchú who was serving as ACOS. This sought to establish the relevance of character in the wider DF. The ACOS was the project lead for the DF Values in Action program and carried this from his previous appointment as Director of Strategic Planning Branch. This Program aims to ensure that our DF Values, Ethos and Standards are reflected in the everyday behaviours of members of the DF. He previously served as Chief Instructor in the Cadet School and so had a deep understanding of the topic.

\section{Data Analysis}

The focus groups and semi-structured interviews supported the use of an inductive, thematic analysis. The flexibility of this approach was most suitable to the nature of this research, an area that is not fully understood and developed within the DF. This allowed the creation of a link between the reviewed literature, the focus group and the sequential set of interviews. This approach offered certain advantages over grounded theory or discourse theory, as 
thematic analysis is not tied to any pre-existing theoretical framework (Boyatzis, 1998). Inductive thematic analysis offers a flexible method of identifying, analysing and reporting on the patterns found in the qualitative data (Braun \& Clarke, 2006). Using Braun and Clarke's six phases of thematic analysis (2006) as the framework for this analysis allowed the synthesis of the information gained through the literature, expanded upon in the focus group and interviews and developed into themes with reference to each other.

The methodology outlined was selected as it offered the most relevant and effective framework for this paper. The methods employed for data collection and analysis address the research question in a post-positivist philosophy, using a qualitative approach. The focus groups provided a detailed set of data that was derived from a near representative sample and shaped the course of the semi-structured interviews. The interviews themselves followed in a sequence that allowed for reflection and an evolving, deepening understanding of the subject from the perspective of the student, officer instructor and School Commandant. This has produced a deep and rich set of data, the findings of which are presented in Part Three.

\section{PART THREE. Research findings}

Part Three will examine and analyse the primary data gathered across the research. This examination will contribute to the understanding gained from the literature review.

\section{Summary of key themes}

The research identified five themes that have been developed through the research process. Those themes are the nature of character, the roles of the Cadet School staff, leadership development at the individual level, the assessment of character and a whole school approach. Each of these themes is expanded and examined to interrogate how it contributes to character development in the DF.

\section{Section 1: The nature of character}

\section{Understanding the nature of character}

Understanding the nature of character is critical to enabling efforts to develop character in cadets and the wider DF. This subject was explored through the focus groups and with the interviewees to establish their understanding of the nature of character and how it is relevant to the DF and challenged my understanding of the subject and how it is applied in the Cadet School.

The focus group expressed their understanding of character using the DF Values in addition to their life experiences. They described events using the terms of Loyalty, Physical Courage and Moral Courage and were able to draw on these to describe some of their experiences. As would be expected from newly commissioned officers, they could recite the Values and give some examples of what was expected. They also used terms such as fairness and integrity that reflect the definitions used by Ros-Morente (2018), and these were used to expand on experiences. Using Bloom's Taxonomy model (Fig 4) as described in the literature review, it can be argued that the newly commissioned officers are at the stage where they can remember and understand the DF Values and are learning to apply them. This is reflected in 
the language used by the focus group; points were clearly articulated using single points of reference from within the DF Values.

\section{Bloom's Taxonomy}

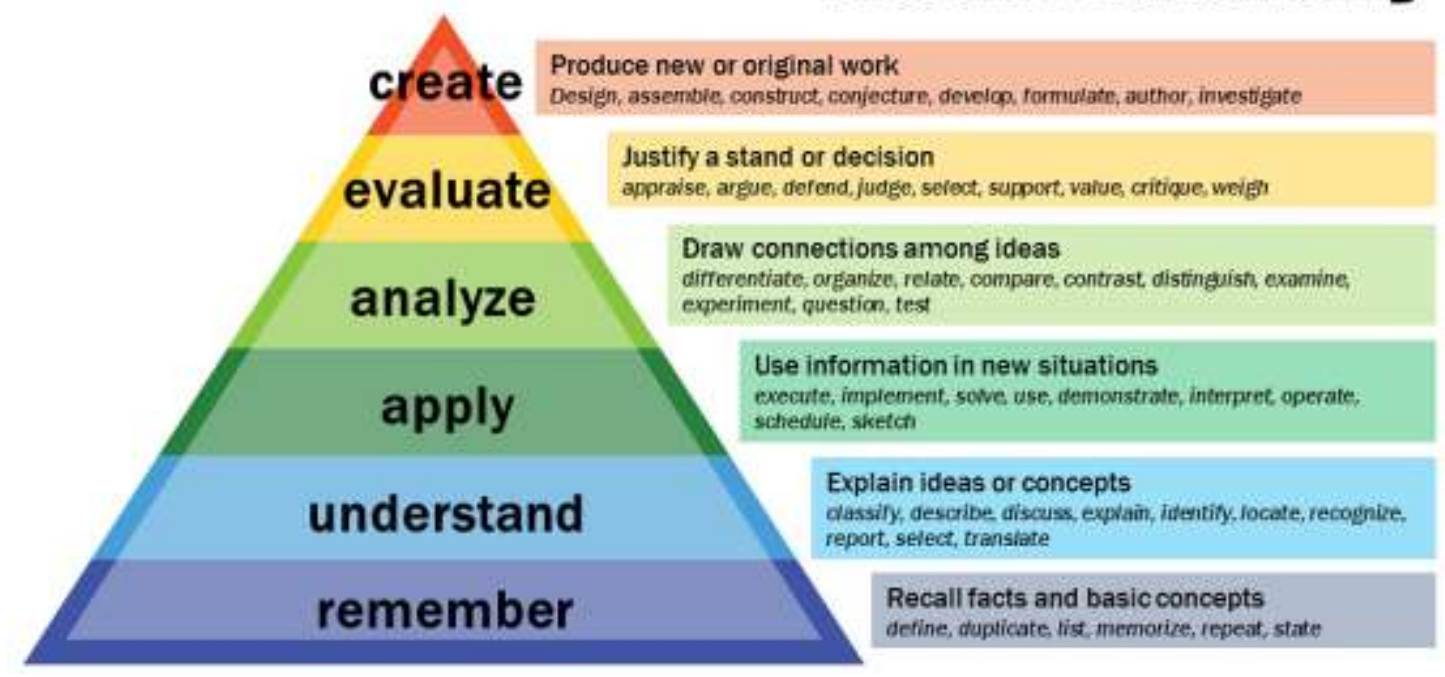

Figure 4. Bloom's Taxonomy of Learning (Figure taken from Armstrong, 2020)

The instructors also heavily used the DF Values to describe the idea of character, using them as a framework in which to explain to the students what was expected of them as potential leaders in the DF. They demonstrated their ability to apply and analyse the DF Values and use them to instruct and assess the students.

The language used by the focus group also provided an insight into where they were in terms of psychosocial development using Kegans (1994) stages. As discussed previously, the newly commissioned officers are likely to be in the second or third order of development, moving from self-interest to interpersonal relationships and reaching for a socialised perspective. In the focus group the differences were evident in the language used. Some of the Focus Group discussed character in terms of themselves or their peers, terms such as loyalty were used to describe helping themselves and their buddies in the Cadet School. Those who were more developed were able to describe character from a more socialised or selfauthoring perspective. This is important when considering their ability to self-direct learning, which is a key requirement in the Cadet Schools model for character development.

What was absent in both instructor and student was a clear cognitive association between the DF Values and character. When asked what character was, both the focus group and instructors reverted to terms such as integrity, honesty, and fairness. Neither group went to the DF Values as a measure of character. This highlights that the knowledge of the DF Values is present, but that the DF Values as the embodiment of character is not clearly articulated. They have not been given the language to describe character.

\section{The DF Values and Character}

In discussing the nature of character with the focus group it was clear that they understood the DF Values and understood that character was important but had not linked the two cognitively. What the findings of this paper highlight is the need for a clear and common 
language to ensure the concept of Values and character are linked. In the interview with the School Commandant he outlined the role of the DF Values, they signpost the direction from the highest levels of the organisation, giving a shared understanding. As described in the Literature Review (Table 3) the DF Values are benchmarked against academic and military values and provide a framework for character education. Brig. Gen. Ó Murchú outlined that these are still relatively new in the DF and work must be done to integrate them, to make them part of our culture. This is the purpose of the DF Values in action program, whereby people see these values daily and learn their importance.

Prof. Kilner of the WPMA highlighted how the language of character needs to be brought in to support these other efforts, it must be "theoretically grounded, robust enough to actually inform actions but simple enough so that everyone can understand it.". This is analogous to tactical training, whereby students are taught a new language; taught about tactics, weapons capabilities, and employment characteristics. They are taught about leadership and battlefield command, and they are given the language to describe what they are doing in practice. Assessments and appraisals are done through this unique language. Kilner applied the same for character, "you must give them the knowledge of character, the vocabulary to describe what it is they are trying to achieve, get them to apply it and assess and give feedback using the lexicon of character." This language will serve to ensure that they learn better from these experiences and that they have the tools to develop character continuously throughout their profession.

Kilner used the analogy of physical fitness to elaborate on this aspect. If you teach students about physical fitness and training, instead of just putting them through a PT program they will be able to use it to develop themselves and others around them. They have a greater chance of understanding why something went wrong and not just what. If you understand something, you can reflect on it and you can talk about it but "if we just make it all behaviour, all practice, if you don't have a sharing of concepts, of definition, you don't learn as much from your action." The focus should be on becoming "smarter about character and not just being told to follow the rules." To do this, we must have the intellectual component and the language of character development.

\section{Conclusion}

The key finding from this section is that the Cadet School is using the DF Values to educate the cadets and that the newly commissioned officers can understand and begin to apply the Values. However, this can be improved by prioritising character education and incorporating the language of character into our training. This can act as a link between the DF Values and character to achieve what the DF Values in action is trying to address bridging "the intellectual gap between words and deeds" (Ó Murchú , 2020).

\section{Section 2: Cadet School Staff}

\section{Who is responsible for developing Character?}

To assess character development in the Cadet School, it was necessary to first examine who is responsible for it. The focus group could not identify one common person who was responsible. The NCO instructors were commonly referenced but the degree to which they aided in character development depended largely on the instructor concerned. Some NCOs 
took an interest in helping the cadets to develop character, however many in the focus groups felt that the NCOs were primarily concerned with competence. The officer instructors were considered more influential in developing character as they provided feedback on leadership and the skills associated with being a commissioned officer. The majority agreed that the Class Officer played a significant role in tying together the various strands of their experiences for them through the feedback and appraisal methods available. The focus group highlighted that the use of the Cadet School Chief Instructor to deliver the Command and Leadership module was successful, in that it was clearly important enough to warrant its own steward. The same approach could be considered for character.

Similarly, the officer instructors interviewed were unable to identify a common individual who was responsible for developing character. The role of all instructors to act as role models was important, with a greater weight placed on the officers and the permanent Cadet School staff to provide mentoring in character. The role of the Cadet School Regimental Sergeant Major (RSM), Class Officer and School Commandant was viewed as important in setting the tone for character development in terms of standards that were to be upheld and to ensure that staff were the standard bearers. The School Commandant ultimately claimed responsibility for approving the cadets for progression through training and commissioning and therefore was responsible for their character. He referred to the standing orders that outline to student and staff the ethos and culture that is expected in the Cadet School and is in the view of the School Commandant the most important document in relation to character development, "I think it's the cumulative effect of syllabus, the standing orders, the staff, the ethos, the tone, the leadership, in the Cadet School brings about character."

\section{Are the staff equipped properly?}

Character development is seen as a cumulative experience and all staff have a role to play, it is therefore important to examine if they have the skills necessary. The Cadet School permanent instructor staff are selected based on experience and ability and are skilled instructors. In addition, they have a vested interest in developing the leadership and character of the cadets. This fact was borne out by the focus group who acknowledged the skill and devotion of the instructors. However, interrogating this matter with the officer instructors illustrates that the increase in numbers has strained this system to a point where there is a need to provide a structure for character development in the syllabus. The officer instructors highlighted that their role and the role of the instructor staff is primarily the delivery of the syllabus and that they have less time to dedicate to providing feedback on performance and development; if it is not in the syllabus, then it is not seen as a priority. The officer instructors also highlighted that there was no clear system to develop character and that it depended on the experience and personality of each instructor as to how effective they were in developing character. This ability is further hindered by the large classes without a relative increase in permanent instructor staff.

\section{Conclusion}

This outlines the issue a hand, that the traditional methods used in the Cadet School are under strain due to the large numbers and that we must better equip our instructors to ensure character is developed coherently. To do this they must understand the nature of character, have a system that supports them and the language to effectively communicate this. 


\section{Section 3: Leadership Development at an Individual Level}

\section{Techniques to develop character}

There are many models for developing character as discussed in the literature review and Kolb's model of experiential learning (Fig 2 ) is one that suits the military training model well. When discussing this with the focus group, they were unaware of any such model, either as recent students, or as instructors responsible for induction and career training in the DF. The Instructors and School Commandant were aware of such models but had not taken them consciously into account in the organisation of training or the development of character in the Cadet School. Kolb's model provides concrete, clear and achievable steps for character education. It requires a skill that is crucial for character development, which is also a tool for continuous personal and professional development, the skill of reflection. One finding from the focus group was that for some, they were not conscious of their development, or how valuable these experiences were. This is a vital opportunity that is currently being missed.

Many of the focus group felt that they had never really reflected on their leadership or the DF Values. It also appears that those who did reflect, did so due to experiences prior to joining the DF. The focus group criticised the nature of the feedback through the various means including the LA150. The School Commandant outlined the value and merits of the LA150 Character Leadership Assessment stating that, contrary to the assertions in Chapter Two, it did provide SMART objectives, but that the way it is being delivered could be reviewed. One interesting observation was the different attitudes towards the appraisal in the focus group primarily due to age and therefore possibly psychosocial development. The cadets at a later stage of psychosocial development were able to take the feedback being offered and to use it to develop aspects of their character. Cadets who were likely to be at an earlier stage of psychosocial development tended to take the feedback on competence and exclude the character. This indicates that those who had the tools for character development were best able to progress and highlights the need to give the cadets the tools to develop, rather than just the competencies to perform.

The instructors mirrored the findings of the focus group and said that their primary role, the delivery of the syllabus did not directly support character education. The instructors identified that this had become increasingly fraught due to the large number of cadets in training. Discussing the delivery of the syllabus the School Commandant and the Instructors acknowledged that we do not provide training on how to reflect, we do not provide time to do it and we do not require cadets to reflect on assessments, feedback or appraisals. The School Commandant did highlight the importance of reflection, "that as we go through our careers, we reflect on our experiences to grow." This highlights the crux of the matter, that as professional officers, we inherently understand the importance of reflection, but organisationally we have not put structures in place to ensure it is effective.

\section{Crucible moments}

Kolb's model depends on concrete experiences to provide a subject to reflect on; these are crucible moments. From the focus group it was found that the most important experiences were different for each individual, that for some it was the first time as Company Orderly Sergeant or for others it was their first time taking control of a Platoon of trained soldiers during an exercise. The focus group agreed that a degree of physical and psychological hardship and the general robustness of military training was key to developing the specific 
character required by the military. Social occasions, sports, adventure training and activities such as organising charitable events were all listed as important. For others development came through peer interaction in their daily lives as cadets and in many ways, this reflects the views of the School Commandant that it is a cumulative experience and Prof. Kilners' observation that the majority "of the development is happening outside of the classroom."

The diverse themes identified by the Focus Group supports the School Commandants and Prof Kilners view that character development is a cumulative effect and not just a training program. What is important is that the Cadet School continues to afford its students these rich experiences and provides the tools to ensure development appropriate to the levels of learning.

\section{Role Models}

The role that relationships and modelling behaviour play in character development is key and was reflected as such by the School Commandant "we try to select the best officers, the best NCOs, because we ultimately want our students to model on those people." The findings from the focus group and instructors concurred with the School Commandant, that providing positive role models who embodied the DF Values and exhibited the type of character expected was essential. These role models fit into Kolb's model in the reflective observation, that the student can give context to their experience by seeing others in action. The focus group highlighted how the role models changed as they developed, moving from section commanders to the officer instructors. The early formative phase is crucial in setting the tone for character development for the remainder of the Cadetship and the NCOs must be equipped with the knowledge and language to develop character. The instructors highlighted the complexity of balancing military socialisation, discipline, and robust training with character development and this is intricately linked to the use of a lexicon of character integrated into training.

The focus group, instructors and School Commandant all agreed that the level of Senior/ Junior Class interaction was limited, particularly due to the larger classes and the focus group felt that there was little relationship between the classes. This type of near peer role modelling is a key skill for continuous professional development and it closely replicates what they will have to do in the units after commissioning, to identify positive role models from their nearpeers and learn from them. Prof. Kilner discussed the importance of peer or near peer role modelling for character development over the course of the West Point Cadet Training, "it's better to have the upper class cadets do a 70 percent job, than officers come in and do a 90 or 100 percent job teaching it because the words are less important than the example from a near peer." The Senior Classes are given the opportunity to instruct and work with the Junior Classes and this is an important first step while still in a relatively sterile environment. For the Seniors it facilitates abstract conceptualisation and active experimentation leading to concrete experience to learn from. For the Junior Classes it provides concrete experience and reflective observation, allowing them to model their behaviour on near peers.

A finding that is common in both the Irish Cadet School and the WPMA is that neither school claims to produce a finished product. The School Commandant outlined that "we are not producing officers of character and competence. We are giving them the basics, but it is only after commissioning that they develop." The processes used in training are designed to ensure that the individual has a degree of character and competence to be commissioned but 
that is only the first step on the journey of development. When discussing this matter, the focus group highlighted how quick and steep the learning curve is once commissioned. At this stage role-modelling is crucial but the focus group highlighted the lack of mentors and role models in units, an issue that was also discussed by the ACOS.

The focus group described how as newly commissioned officers they were learning from experience but not necessarily reflecting on what these experiences meant to them, as one officer stated, "I'm not sure I have ever really reflected on my leadership". This highlights the fact that the Cadet School should be equipping the cadets with the values and skills needed post commissioning, this would then support the DF Values in action program. Prof. Kilner highlighted the value of teaching character development to cadets as a means of enhancing the wider organisation because "these new officers are responsible not just for the climate of the unit, but for the character development of their soldiers." This would then support the DF Values in action program as described by Brig. Gen Ó Murchú "to bring about the real and meaningful integration of DF Values into the everyday activities of the DF."

\section{Conclusion}

The continued efforts to provide high quality role models in the officer and NCO instructor staff of the Cadet School is essential, as this formative period is crucial in the individuals development as a leader of character. The opportunity afforded by the Senior/ Junior Class interaction could be broadened and given structure, enhancing the experience of the cadets, and providing a crucial skill essential post commissioning.

To develop leadership at the individual level it is essential that the individual is given the tools to do so. Using an adapted Kolb's model of experiential learning to develop an appropriate system would ensure that the opportunities that already exist are exploited fully (Fig 5). To teach the skill of reflection and to ensure that it is implemented would be a significant step in the character development of the cadets and provide a tool for continuous professional development. This would support the DF Values in action program by providing a practical tool to bridge the gap between concept and action.

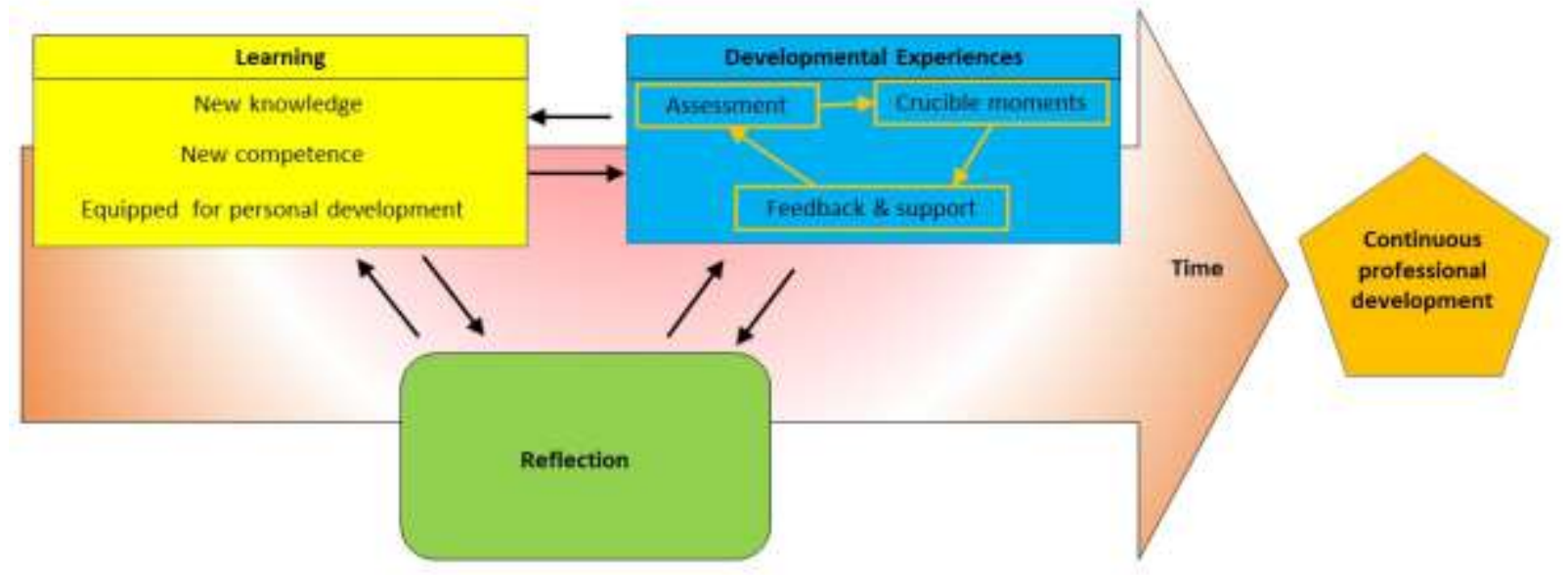

Figure 5. Adapted Kolb's Model (adapted by author) 


\section{Section 3: Character Assessment}

\section{Character or Competence}

The system of assessments and appraisals in the Cadet School is designed to ensure that the cadets have the character and competence to be commissioned as officers. The focus group and instructors were critical of the nature of the assessments in the Cadet School and highlighted that one could pass a field assessment without your character being really tested. They felt that these assessments were 'check the box' and did not provide much insight into character. The focus group outlined that for some cadets, the single priority was assessments as they were aware that this determined class places, seniority, and preference of unit upon commissioning. The School Commandant reiterated the need for a level playing field "it is a competitive process after all." He also acknowledged that there was scope to examine the nature of the practical assessments to provide greater opportunities for character development, particularly in the later phases of the Cadetship. These assessments could be improved by affording the cadets the freedom to fail.

The subject of freedom to fail is important in Kolb's model, whereby the learner must be given scope to make decisions and learn from the positives and the negatives. Prof. Kilner outlined its importance in the later stages of the Cadetship, where the student understands the fundamentals. They should be exposed to challenges where there is uncertainty and doubt, experiences where there are complexities and there is a risk of them failing the task. This failure does not mean a failed assessment but provides for abstract conceptualisation and a later opportunity for active experimentation. For this to be achieved the assessment must be designed to look at their behaviours and interrogate their thought processes and their understanding.

The appraisals following assessments were another area highlighted by the focus group as being primarily focused on competence. As described in the literature review, the primary assessment tool is the LA150 and the School Commandant reiterated that this was not a tool for development but a means of delivering an appraisal. The focus group found this to be a one-way process, whereby they were given the results of their exams and told to develop. Without giving the cadets the tools to self-develop this proves inherently problematic, particularly for those who are less developed psychosocially and reinforces the earlier recommendation regarding equipping cadets with the tools, including reflection, to develop their own character and leadership.

\section{Discretion to assess character}

The matter of assessing a cadet's character and suitability for commissioning was discussed with the officer instructors and the School Commandant. The balance between the need to provide a level playing field for assessing cadets in a competitive environment and to ensure that officers commissioned have the character required is challenging. The School Commandant outlined that the systems in place are designed to provide protection and transparency to the staff and students. The officer instructors felt that with the assessment systems biased towards competence, it was difficult to build a sufficient case to determine if a cadet's character was unsuitable. 


\section{Conclusion}

The assessment system for the Cadet School is primarily competence-based and the assessment of character is a subjective assessment at the end of each phase. If the Cadet School is to progress towards a more developed Character Development program, there is a need to devise an assessment, appraisal and feedback mechanism that provides concrete experiences, guided reflection, abstract conceptualisation and active experimentation in order to foster these skills as part of continuous professional development.

A second benefit of this approach would be to strengthen the position of the instructors and the School Commandant when it came to assess the suitability of a cadet for commissioning. By balancing the assessment of character and competence, it could improve ability of the Cadet School to determine whether someone has the character to be commissioned.

\section{Section 4: Whole School Approach}

\section{The PRIMED Model}

The whole school approach as described by Berkowitz, Bier and McCauley (2017) uses the model of Prioritisation, Relationships, Intrinsic motivation, Modelling, Empowerment and Developmental (PRIMED) as a framework for delivering character development programs. Through the interviews and focus group, the aspects of this model were examined.

The focus group and the officer instructors reported that they saw the priority in the Cadet School as being the delivery of the syllabus and the assessment of competence and not on character. This point was accepted by the School Commandant, but he outlined the cumulative effect of the Cadet Program on character. The internalisation of motivation and character values was seen by all as being essential and that to a large extent it is the case in the Cadet School. The process of providing an external locus for behaviour is inherent in the military socialisation process in phase one and two but as the student develops, there is a greater degree of responsibility placed on them to motivate themselves to perform and to adhere to the DF Values.

The role that relationships and modelling behaviour play in character development and the extent to which they are present has previously been discussed as part of this chapter. The Cadetship is inherently experiential and developmental and is essentially a formative experience when seen as a whole and as the School Commandant described, that with the passage of time the entire Cadetship becomes seen as one single experience.

The PRIMED model has implications for the DF Values in action program as well. Brig. Gen Ó Murchú outlined the benefits of having a system that has character at is core, as being more supportive of the DF Values in action program. A review of the manner in which the Cadet School approaches character education and assessment could be benefical to the wider DF.

\section{Recommendations}

Using the PRIMED model lens, the Cadet School provides many of the aspects of an effective character development program. The area that could significantly enhance the effectiveness is the prioritisation of character to at least on par with competence. The School Commandant 
correctly outlined that the effect of character development is being achieved through the current system and the cumulative effects of the Cadet syllabus and standing orders. However, both Prof. Kilner and Brig. Gen Ó Murchú suggest that an approach where character was prioritised, while maintaining standards of competence could be of benefit to the Cadet School and the wider DF.

\section{Conclusion}

A useful model to summarise these findings is provided in Figure 6 which shows how the three pillars of the Cadet School (structures, knowledge and development) embedded within the whole school approach provide the foundation for continuous professional development and the DF values in action. The findings of the research indicate that the Cadet School has, and continues to, produce officers of character and competence, however it achieves it through a competence-based syllabus supported by the ethos of the Cadet School in an indirect approach. The cumulative experience fundamentally shapes an individual's character and at commissioning they are trusted to serve as officers of the DF. However, the findings also show that the commissioning is the start and not the end of their professional development and that the Cadet School should equip them with the skills needed.

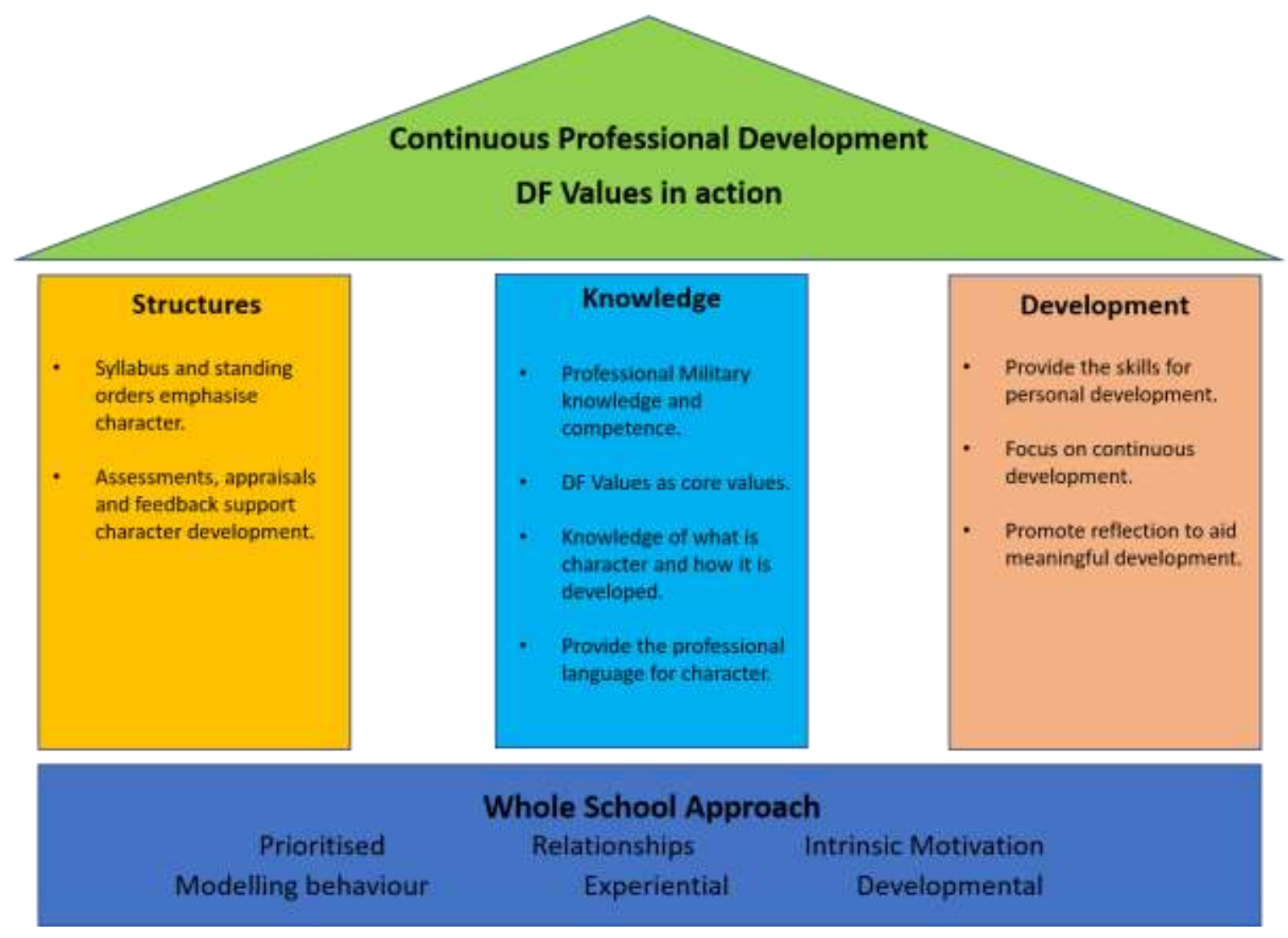

Figure 6. Conceptual Framework for character-based program (by author)

Many of the aspects of a successful character development program are already in place, but when examined the bias in the syllabus towards competence means that many valuable learning opportunities are not realised to their full potential. Figure 6 illustrates an approach to character development that can be contrasted with the current model (see Fig 3). This model incorporates a whole school approach, supporting the structures, knowledge, and a developmental focus which could improve the capacity for the continuous professional development of the individual. These skills would likely lead to a greater awareness and 
understanding of character across the DF and thereby support the DF Values in action program.

\section{PART FOUR - Conclusions and recommendations}

This paper sought to determine how effectively the Cadet School is able to identify leaders of character. The findings of the research indicate that the Cadet School is producing officers of character and competence, with the focus on competence. Many of the systems in the Cadet School provide character education through experiential learning but what is apparent is that the bias towards competence means that character education is not prioritised. There is significant scope to develop the existing systems and structures to enhance character education and provide officers who are equipped to develop post commissioning, providing a better balance between character and competence.

\section{Implications}

The Cadet School is the formative experience for most army officers and it is essential to address the issue of character early on to ensure our future leaders are well prepared to embark of their leadership journey. For the Cadet School there is a need to examine its program for character development. This should not require a complete overhaul of the syllabus and systems but rather an examination and reimagination of the existing systems. By reviewing them with a focus on character the opportunities that exist, including excellent role models and diverse crucible moments, can be maximised and the cadets equipped with the tools needed to direct their own development with guidance and support from the system. This would provide officers who are capable of continuous professional and personal development and crucially have the skills to do so in a wider context.

A fully developed character education system that is integrated into existing leadership and competence training would greatly enhance the DF Values in action program. By establishing the cognitive link between DF Values and character and providing a concrete system for development, the DF Values can bridge the gap between words and deeds.

A clearly defined and proven character development system that has been trialled and tested by the DF could be exported as a model for other organisations. The DF has long been seen as a standard bearer in terms of leadership and trust in the public sector (Boyle, 2019). The development and implementation of an effective character development system could then be of great value to others who rely on organisational values and the character of their personnel.

\section{Recommendations}

The Cadet School provides a formative experience and for years has provided the DF with officers who have the character and competence to lead. The cumulative experience provides the individual with a myriad of role models and growth opportunities, and the judgement and experience of the staff is critical in this. The ethos of the Cadet School, and the standards of its staff and students must continue to develop.

Opportunities exist to provide a more structured approach to character development, to ensure that each cadet maximises on the experiences afforded them and to assist the staff 
in determining how an individual is progressing. This could be achieved by overlaying a character development model on the existing structures and focusing on areas that can be integrated to provide a coherent character and competence program. This would synthesise aspects of character education that are most relevant and beneficial for the Cadet School and would most contribute to the wider DF Values in action. This should be developed as a priority based on best practice within the DF and in other militaries.

The successful implementation of a character development program within the Cadet School would have benefits for the wider DF, as outlined previously. The model used in the Cadet School could be assessed, modified, and provide a character development program for other DF Leadership training courses.

\section{Further Research}

The current study should be repeated or a similar one carried out in a few years to reassess character development in the Cadet School. This could establish if the current problems persist and would examine the effectiveness of the implementation of a program for character development should one have been put in place. This research could then provide a basis for the analysis of the effectiveness of character education in the Cadet School and across the wider DF.

\section{Conclusion}

Leadership is primarily a function of who you are, for this is the foundation of everything you do. How do you build leaders? You first build character. Jim Collins (2004)

The above quote captures the essence of this paper. Character is not an abstract concept that has peripheral relevance to the military. Character is the essence of leadership, which in turn is key to military operations. Therefore, its development should not be left to chance or to an indirect process and it must be integrated into the training of our leaders. This paper has outlined the tools that are available to do so and suggests that it can be integrated into our training, first in the Cadet School and then to the wider DF. Failure to address the identified deficiencies in character development will continue to impact on the effectiveness of our junior leaders and their character as military officers. The DF Values provide us with a framework for character, the DF Values in action make them visible in our day to day activities. A relevant, concrete, character development program would assist in making the DF Values an integral part of our leadership philosophy, ensuring that the DF is producing leaders of character and competence.

Please note that the views expressed in this article are those of the author alone and should not be taken to represent the views of the Irish Defence Forces, the Command and Staff School or any other group or organisation. 


\section{BIBLIOGRAPHY}

Ackerman, C. (2019). Big Five Personality Traits: The OCEAN Model Explained. Available at PositivePsychology: https://positivepsychology.com/big-five-personality-theory/ (Accessed: 05 December 2019)

Agar, M. H. (1986). Speaking of ethnography. Beverly Hills, CA: Sage.

Antonesa, M., Fallon, H., Ryan, A., Ryan, A. B., Walsh, T., \& Borys, L. (2006). Researching and writing your thesis. Maynooth: MACE.

Armstrong, M. (2009). A Handbook of Human Resource Management practice (11th Edition). London: Kogan Page.

Armstrong, P. (2020). Bloom's taxonomy. Retrieved from Vanderbilt University Center for Teaching: Availbale at https://cft.vanderbilt.edu/guides-sub-pages/blooms-taxonomy/ (Accessed: 04 April 2020)

Banicki, K. (2017). The character-personality distinction: An historical, conceptual, and functional investigation. Theoretical Psychology, 50-64. https://doiorg.ucd.idm.oclc.org/10.1177/0959354316684689

Bardi, A., \& Schwartz, S. H. (2003). Values and behavior: Strength and structure of relations. Personality and Social Psychology Bulletin, 29(10), 1207-1220.

Bartone, P. T., Snook, S. A., Forscythe, G. B., Lewis, P., \& Bullis, R. C. (2007). Psychosocial development and leader performance of military officer cadets. The Leadership Quarterly, 18(5), 490-504.

Berkowitz, M. W. (2012). Moral and character education. (K. R. Harris, S. Graham, \& T. Urdan, Eds.) APA Educational Psychology Handbook Vol. 2: Individual Differences and Contextual Factors.

Berkowitz, M. W., Bier, M. C., \& McCauley, B. (2017). Toward a science of character education: Frameworks for identifying and implementing effective practices. Journal of Character Education, 13(1), 33-51.

Bleich, M. R. (2015). Defining moments in character education. The Journal of Continuing Education in Nursing, 46(6), 247-249.

Boe, O., \& Bang, H. (2017). The Big 12: The most important character strengths for military officers. Athens Journal of Social Sciences, 4(2), 161-174.

Boyatzis, R. E. (1998). Transforming qualitative information: Thematic analysis and code development. California: Sage Publicatons.

Boyle, R. (2019). Public sector trends. Dublin: Institute of Public Adminstration.

Braun, V., \& Clarke, V. (2006). Using thematic analysis in psychology. Qualitative Research in Psychology, 3(2), 77-101.

Brown Wright, G. (2011). Student-centered learning in higher education. International Journal of Teaching and Learning in Higher Education, 23, 92-97. Availale at http://www.isetl.org/ijtlhe/ (Accessed 12 September 2019) 
Bryman, A. (2008). Social research methods (3rd edition). New York: Oxford University Press. Carter, S. L. (1996). Integrity. New York: Basic Books.

Center for the Army Profession and Ethics. (2016). Developing the character of trusted army professionals. Washington: U.S. Army Training and Doctrine Command.

Collins, J. (2004). Foreword for 25th Anniversary Edition. In S. R. Covey, The 7 habits of highly effective people: Powerful lessons in personal change. 25th anniversary edition. New York: Simon \& Schuster.

Creswell, J. W. (2007). Qualitative inquiry \& research design: Choosing among . London: SAGE Publications.

Damon, W. (2002). Bringing in a new era in character education. Stanford, California: Hoover Institution Press.

Damon, W. (2008). The Path to purpose: How young people find their calling in life. New York: The Free Press.

Damon, W. (2011). Failing liberty 101: How we are leaving young americans unprepared for citizenship in a free society. Stanford, California: Hoover Institution Press.

Damon, W., \& Colby, A. (2015). The power of ideals: The real story of moral choice. New York: Oxford University Press.

Danziger, K. (1997). Naming the mind: How psychology found its language. Cambridge: Cambridge Univeristy Press.

Denzin, N. K. (1997). Interpretive ethnography: Ethnographic practices for the twenty first century. London: Sage.

Department of Education and Science. (2000). White paper on adult learning. Dublin: Government Stationary Office.

Devettere, R. J. (2002). Introduction to virtue ethics: Insights of the ancient Greeks. Washington DC: Georgetown Univeristy Press.

Ellenberger, H. F. (1970). The discovery of the unconscious. New York: Basic Books.

Erikson, E. H. (1959). Identity and the life cycle: Selected papers. New York: International Universities Press.

Erikson, E. H. (1968). Identity: Youth in crisis. New York: Norton.

Erikson, E. H. (1982). Insight and responsibility. New York: Norton.

Fielding, J., \& Gilbert , N. (2012). Understanding social statistics (2nd ed.). London: Sage Publications.

Fisher, C. B., \& Lerner, R. M. (2005). Encyclopedia of applied developmental science. Thousand Oaks, California: Sage Publications.

Forbes. (2012) Norman Schwarzkopf: 10 quotes on leadership and war. Available at: www.forbes.com/sites/kevinkruse/2012/12/27/norman-schwarzkopf-quotes/ (Accessed: 09 March 2020) 
Freire, P. (2000). Pedagogy of the oppressed (30th edition). New York: Continuum Performance.

Gilligan, C. (1982). In a different voice: Psychological theory and women's development. Cambridge, Mass: Harvard University Press.

Gini, A., \& Green, R. M. (2013). 10 Virtues of Outstanding Leaders : Leadership and Character, 2013. John Wiley \& Sons, Incorporated.

Goldie, P. (2004). On personality. New York: Routledge.

Hartman, E. (2013). Aristotle on character formation. (C. Luetge, \& D. Springer, Eds.) Handbook of the Philosophical Foundations of Business Ethics, 67-88. doi:https://doi.org/10.1007/978-94-007-1494-6_46

Headquarters Department of the Army. (2015). FM 6-22 Leader Development. Washington, DC: US Department of the Army.

Heyvaert, M., Maes, B., \& Onghena, P. (2013). Mixed methods research synthesis: Definition, framework, and potential. Quality and Quantity, 47(2), 659-676.

Howard, R. A., Carver, C. A., \& Lane, W. D. (1996). Felder's learning styles, Bloom's taxonomy, and the Kolb learning cycle: Tying it all together. United States Military Academy, 227-232.

Josephson, M. (1992). Aspen Declaration. Available at: https://whatwillmatter.com/tag/aspen-declaration/ (Accessed 21 November 2019)

Jung, C. G., Read, H., Fordham, M., \& Adler, G. (1983). The collected works of C.G. Jung. New York: Pantheon Books.

Kegan, R. (1982). The evolving self: Problem and process in human development. Cambridge, MA: Harvard University Press.

Kegan, R. (1994). In over our heads: The mental demands of modern life. Cambridge, MA: Harvard University Press.

Keohane, C. (2019). Leadership: The Cadet School. Signal, 21-24.

Knowles, M. (1998). The adult learner. Huston: Gulf Publishing Company.

Kohlberg, L. (1971). From is to ought: How to commit the naturalistic fallacy and get away with it in the study of moral development. New York: Academic Press.

Krathwohl, D. R. (2010). A revision of Bloom's taxonomy: An overview. Theory Into Practice, 41, 212-218. Available at https://doi-org.jproxy.nuim.ie/10.1207/s15430421tip4104_2

Krueger, R. A., \& Casey, M. A. (2000). Focus groups: A practical guide for applied research. Thousand Oaks, CA: Sage Publications.

Luther, J. (2009). The quality of leadership. In M. Hansbury, The Quality of Leadership. New Delhi: Epitome Books.

Manolis, C. (2013). Assessing experiential learning styles: A methodological reconstruction and validation of the Kolb learning style inventory. Learning and Individual Differences, 23, 44-52. 
Mason, J. (2002). Qualitative Researching. London: Sage.

Matthews, M. D., Eid, J., Kelly, D., Bailey, J. K., \& Peterson, C. (2006). Character strengths and virtues of developing military leaders: An international comparison. Military Psyhcology, S57-S68.

McGrath, R. E. (2018). What is character education? Development of a prototype. Journal of Character Education, 14(2), 23-35. Available at https://search-proquest-

com.jproxy.nuim.ie/docview/2155004613?accountid=12309 (Accessed: 19 September 2019)

McLeoud, S. (2017). Kolb's Learning Styles and Experiential Learning Cycle. Simple

Psychology. Available at: https://www.simplypsychology.org/learning-kolb.html (Accessed:

15 December 2019)

Miller, C. (2013). Character and moral psychology. Oxford: Oxford University Press.

Molloy, C. (2019). President salutes Defence Force values and those who uphold them.

Available at: https://www.catholicireland.net/president-salutes-defence-force-valuesuphold/ (Accessed: 05 Febuary 2020)

Nafea, S. M., Siewe, F., \& He, Y. (2019). On recommendation of learning objects using FelderSilverman learning style model. Institute of Electrical and Electronic Engineering, Available at: https://ieeexplore-ieee-org.jproxy.nuim.ie/document/8798626 (Accessed: 06 December 2019)

Narvaez, D. (2008). Human flourishing and moral development: Cognitive and neurobiological perspectives of virtue development. (L. Nucci, \& D. Narvaez, Eds.) Handbook of Moral And Character Education, 310-327.

New Zealand Defence Forces. (2017). Vision, mission, ethos and our values. Auckland: NZDF.

Niemiec, R. (2013). VIA character strengths: Research and practice (The First 10 Years). In , ch 2: In W.-B. a. Psychology, HH Knoop, A Delle Fave (eds), Dordrecht: Springer.

Óglaigh Na hÉireann. (1996). Administration instruction 1/96. Dublin: Defence Forces Printing Press.

Óglaigh Na hÉireann. (2012a). Administrative instruction A3 (New Series) Cadets. Dublin: Defence Forces Printing Press.

Óglaigh Na hÉireann. (2012b). L.A. 150 A Record of training. Dublin: Defence Forces Printing Press.

Óglaigh Na hÉireann. (2015). Defence Forces capstone doctrine. Dublin: Defence Forces Printing Press.

Óglaigh Na hÉireann. (2016a). TS Inf 2016 The standard cadet course. Dublin: Defence Forces Printing Press.

Óglaigh Na hÉireann. (2016b). Defence Forces leadership doctrine. Dublin: Defence Forces Printing Press.

Óglaigh Na hÉireann. (2017). Cadet School standing orders. Dublin: Defence Forces Printing Press. 
Overton, W. F. (2015). Process and relational developmental systems. (W. F. Overton, \& P. C. Molenaar, Eds.) Handbook of Child Psychology and Developmental Science Vol. 1: Theory and Method, 9-62.

Park, N., Peterson, C., \& Seligman, M. (2004). Strengths of character and well-being. Journal of Social and Clinical Psychology., 603-619.

Patton, M. Q. (2014). Qualitative research \& evaluation methods. Integrating theory and practice (4th ed.). London: SAGE Publications Inc.

Peterson, C., \& Seligman, M. E. (2004). Character stregths and virtues: A handbook and classification; Volume 1. New York: Oxford University Press.

Piaget, J. (1972). The psychology of the child. New York: Basic Books.

Pratt, M. W., \& Diessner, R. (1991). Four pathways in the analysis of adult development and aging: Comparing analyses of reasoning about personal-life dilemmas. Journal of Psychology and Aging, 6(4), 666-675.

Ros-Morente, A. (2018). An examination of the relationship between emotional intelligence, positive affect and character strengths and virtues. Anales de Psicología, 34(1), 63-67.

Schein, E. H. (1992). Organizational culture and leadership. San Francisco: Jossey-Bass.

Schroeder, K. (1995). In brief ... character counts. The Education Digest, 60-75. Retrieved Available at: https://search-proquest-

com.jproxy.nuim.ie/docview/218173384?accountid=12309 (Accessed: 03 December 2019)

Schwartzkopf, H. N. (1991). General Norman Schwartzkopf Speech to West Point Corps of Cadets. New York. Available at: https://www.youtube.com/watch?v=uGfrMzqNZqc (Accessed: 05 January 2020)

Scott-Lennon, F., \& Barry, F. (2008). Performance management: Developing people and performance. Dublin: Performance Management Briefs.

Silverman, D. (2000). Doing qualitative research: A practical handbook. Thousand Oaks CA: Sage.

Skinner, B. F. (1971). Beyond freedom and dignity. . New York: Knopf.

Soloman, R. (1996). A handbook for ethics. Orlando: Harcourt Brace.

Tough, P. (2011). What if the secret to success is failure? New York Times. Available from: https://www.nytimes.com/2011/09/18/magazine/what-if-the-secret-to-success-isfailure.html (Accessed 04 Febuary 2020)

UK Ministry of Defence. (2014). Developing leaders: A British Army guide. Surrey: The Royal Military Academy Sandhurst.

UK Ministry of Defence. (2014). Values and standards of the British Army. Hampshire: Army Headquarters.

United States Military Academy. (2018). West Point character program (Gold Book). New York: United States Military Academy.

Weimer, M. (2002). Learner-centered teaching: Five key changes to practice. San Francisco: Jossey-Bass. 
West Point Military Academy. (2018). West Point leader development system. New York: United States Military.

Wolcott, H. (2001). Writing up qualitative research (2nd edition). Thousand Oaks California: Sage Publications.

Wolfgang, A., \& Berkowitz, M. W. (2012). Moral education and character: Their relationship and roles in citizen education. Journal of Moral Education, 35(4), 495-518. Available at: https://www.tandfonline.com/doi/abs/10.1080/03057240601012204 (Accessed 25 September 2019)

Yin, R. K. (2008). Case study research design and methods (4th ed.). California: SAGE Publications 
Developing Leaders of Character 